\title{
Import Competition in the Manufacturing Sector in Peru: Its Impact on Informality and Wages
}

\author{
Fernando Morales $^{a}$, Martha Denisse Pierola ${ }^{b, \downarrow}$, Dennis Sanchez-Navarro ${ }^{c}$ \\ ${ }^{\mathrm{a}}$ World Bank \\ $\bowtie$ fernandomove@hotmail.com \\ ${ }^{\mathrm{b}}$ World Bank \\ $\bowtie$ mpierola@worldbank.org "Corresponding author \\ ${ }^{\mathrm{c}}$ World Bank \\ $\bowtie$ dsancheznavarro@worldbank.org
}

\begin{abstract}
This paper studies the impact of import competition from China on labor outcomes in the Peruvian manufacturing sector in 2001-2010. Using data from the Peruvian Household Survey, we use a two-step procedure to evaluate the impact of the surge in imports from China on the likelihood of having an informal job and on wages in both the formal and informal sectors. On the first step, the results suggest that greater import competition increased - albeit weakly - the likelihood of having an informal job for workers with elementary education. On the second step, we find that the surge in imports from China was detrimental to wages of the least educated individuals with informal jobs - with no education and elementary education - , although we also find that this result is mostly driven by the presence of self-employed among informal workers. We also observe a wage increase among workers with formal jobs and elementary and high school education. These results are robust to the inclusion of different exclusion restrictions and even after accounting for industry-level growth which was strong during the period studied.
\end{abstract}

Article History: Received: April 252020 / Revised: July 172020 / Accepted: September 32021 Keywords: Import competition; Informality; Wages

JEL Classification: F14, F16, J23

\section{Acknowledgements}

The authors are thankful to Nina Pavcnik, Mauricio Mesquita Moreira, Christian Volpe, Ana Margarida Fernandes, Marisol Rodriguez-Chatruc, Juan Blyde, Valeria Faggioni and two anonymous referees for valuable comments. The views and interpretations in this paper are strictly those of the authors and should not be attributed to the World Bank, its Board of Directors, or the countries they represent. 


\section{Introduction}

Following China's transition to a market-oriented economy and its accession to the WTO, its exports experienced outstanding growth, especially in 2000-2005. China has now become the leading trade partner for most countries around the globe. Its share in world exports tripled from $6 \%$ in 2000 to $18 \%$ in 2015 ; in manufacturing, its share went from $7 \%$ to $17 \%$ during the same period. ${ }^{1}$

The surge in China's exports - the so-called China shock - and its impact on labor markets has been the focus of a growing body of literature. Although a considerable part of this literature has studied the heterogeneous impact of the surge on manufacturing employment in local markets in the United States (Autor et al., 2013, 2016; Acemoglu et al., 2016), studies focusing on other regions (such as Europe, Asia, and Africa) reveal that the effects have been felt worldwide - see Mion and Zhu (2013) for a study of Belgium, Balsvik et al. (2015) on Norway, Malgouyres (2016) on France, Cabral et al. (2018) on Portugal, Yamashita (2017) on Japan and Edwards and Jenkins (2015) on South Africa, among others. In all these studies, the authors find significant and heterogeneous impacts on wages, employment, and inequality, with different intensities depending on workers' skill levels.

Latin American countries have not been immune to the impact of the China shock either. Country-specific analyses within the region also reveal that China has had a heterogeneous impact on manufacturing employment. For instance, Blyde et al. (2016) find that the surge in Chinese manufacturing goods had a negative effect on formal employment and increased informality in Mexico. However, this impact was more severe for production workers than nonproduction workers. In Colombia, Molina (2017) finds a detrimental impact on employment growth - a 1percentage-point increase in import penetration reduced employment growth by 8 percentage points. In Brazil, Paz (2017) also finds a negative impact on the manufacturing employment level.

This paper adds to this series of analyses by evaluating the heterogenous impact of the China shock on the labor market in the Peruvian manufacturing sector. The Peruvian experience provides an interesting context for two reasons. First, the Peruvian labor market has one of the highest rates of informality in Latin America. In fact, Peru has the third-highest informality rate in the region among the poorest quintile of the per-capita family income distribution. ${ }^{2}$ Within the manufacturing sector, nearly $80 \%$ of the labor force are workers who do not contribute to the social security system. ${ }^{3}$ While informality could be seen as being preferable to a paralyzed economy with regulation-induced rigidities (Loayza, 2007), it is generally deemed undesirable because firms in this sector are normally smaller and less productive (Levy, 2018); and informal jobs - whether in unregistered firms or registered firms that do not comply with labor-market regulations - are associated with worse working conditions (Goldberg and Pavcnik, 2003). Reducing informality is one of the most important challenges facing the Peruvian economy, and

\footnotetext{
${ }^{1}$ Figures based on COMTRADE.

${ }^{2}$ Informality in Peru also ranks among the highest in the region in all other income quintiles, according to OECD/CIAT/IDB (2016).

${ }^{3}$ Based on Peruvian National Household Survey (ENAHO).
} 
thus, if we want to assess the impact of the China shock on the Peruvian labor market, it is important to understand how the inflow of manufacturing goods from a low-cost competitor like China impacted informality in the Peruvian labor market. In addition, focusing on informality is also particularly important if we consider that several studies conducted in Latin America, analyzing the effects of trade shocks (Goldberg and Pavcnik, 2003; Dix-Carneiro and Kovak, 2019) show that some effects (e.g., productivity gains and welfare) can be severely understated in the tradable sectors when the informal sector is omitted (Dix-Carneiro et al., 2021). Thus, in this work, we focus on informality and we evaluate the effects on both workers, those with formal and with informal jobs separately.

Second, another important aspect to consider in the study of the Peruvian manufacturing sector during the 2000s is that, as a result of its own structural reforms and favorable external conditions (the commodities boom), Peru experienced unprecedented growth in parallel with and throughout the peak of the surge in China's exports to the world. Consistent with the economy's growth, the Peruvian manufacturing sector's output and labor force expanded throughout the decade. In a context like this, a booming economy may either attenuate the negative effects from the surge for firms competing with imported final (substitute) goods, or it may also propel growth for other firms that use the low-cost imports of intermediate (complementary) goods from China. ${ }^{4}$ We control for these potential confounding factors by accounting for variation in growth rates by industry in our analysis.

Using data from the Peruvian Household Survey (Encuesta Nacional de Hogares, ENAHO) for 2001-2010 and following Paz (2014), we address these questions and study the impact of the China shock on informality and then on formal and informal wages. ${ }^{5}$ For this analysis, we define informality at the individual level, based on whether the worker reports payments to the social security system, regardless of whether they work for a formal or informal establishment (see Támola, 2014). ${ }^{6}$ While we find no evidence that the China shock had a strong overall impact on the probability of having an informal job, we break down our analysis by workers' education levels and find that the surge in import competition increased - albeit weakly - the likelihood of having an informal job among the less-skilled workers, those with elementary education.

Turning to the impact on wages, we find mixed results, with impacts varying by the individual's level of education. ${ }^{7}$ First, we observe that the impact was detrimental to the least skilled workers with informal jobs - with either no education or elementary education. These results are

\footnotetext{
${ }^{4}$ The impacts of the China shock cannot be expected to be the same across industries. While the surge in lowcost Chinese imports may have pushed some firms competing with similar goods produced domestically (arguably the less productive firms in a Melitz (2003)-like set up) to cut costs (including labor) and putting a downward pressure on wages; firms in industries producing goods that are complementary to those imported at a lower cost may have been favored with the surge and expand.

${ }^{5}$ Despite the self-reporting nature of the answers in a Household Survey, ENAHO is the most reliable source of information for individual level labor outcomes in Peru. Although the use of self-reported variables could lead to possible bias, these data are the only official source formally used by the national agency of statistics to characterize the official employment figures at the national level. Additionally, it is worth noting that when the idiosyncratic measurement error occurs in the dependent variables, our estimators remain consistent and unbiased.

${ }^{6}$ Further explanation on the definition of informal worker will be provided in Section 3.1.

${ }^{7}$ Paz and Kapri (2019) also find varying results by workers' skill-level.
} 
supportive of the idea that low-cost imported (final) goods compete directly with some goods produced locally, affecting the demand for the latter negatively, and putting a downward pressure on the wages of workers in these industries. While these results are robust to the use of an alternative exclusion restriction in the estimation of the probability of having an informal job and to the inclusion of a control variable that accounts for the industry-level growth, further analysis accounting for self-employed workers - who are largely found in the sample of informal workers - reveals that the detrimental effects are mostly driven by their presence in the sample. Second, we also find a positive and significant impact on wages of individuals with formal jobs and with elementary and high school education. These results may be due to complementary dynamics between some groups of imported (intermediate) goods and some goods produced locally, or they could just simply be reflecting an income effect arising from the larger purchasing power of individuals who can now afford more (imported) goods at lower prices and thus, increase their demand for goods in other industries/sectors. These results are also robust to the inclusion of a different exclusion restriction, of a variable accounting for industry-level growth, and to the exclusion of self-employed workers.

Our work relates to different strands of the literature. First, regarding the impact of the China shock, we follow the group of studies that exploit variation in import exposure to Chinese competition at the industry level - Bernard et al. (2006) and Mion and Zhu (2013). ${ }^{8}$ One difference between our study and these papers is that our analysis focuses on workers and informality as opposed to plant-level outcomes. However, in terms of the findings themselves, our results are largely consistent with the results in all the analyses previously mentioned. We find significant heterogeneity in the effects of the import surge that vary according to workers' level of education.

Our study also related to previous studies on the impact of the China shock in Peru. In fact, some of these studies, looking at the impact of the China shock on Peruvian exports, suggest that the tougher competition from Chinese products acted as an incentive for some Peruvian exporting firms to differentiate themselves from Chinese supply and enhance their productivity and/or expand. For instance, Rabanal and Rabanal (2016) look at firm-level Peruvian exports from all sectors and find that Chinese competition had a positive effect on Peruvian firms' exports to a given destination. This evidence is consistent with the experience of the Peruvian apparel industry, which responded to the intense competition from China by reallocating idle factors and upgrading quality (Medina, 2021). ${ }^{9}$ This study complements the existing research by providing evidence on the impact of the China shock in Peru from the worker's perspective.

Finally, this paper is also connected to the literature that addresses the effect of trade shocks on informality and suggests that trade shocks, such as greater exposure to import competition, impact informality by pushing firms in the domestic market to hire more informal workers in an attempt to cut labor costs. Dix-Carneiro and Kovak (2017) find that regions in Brazil that were more exposed to trade because of larger tariff cuts experienced a prolonged decline in

\footnotetext{
${ }^{8}$ Another methodological approach that is widely used in the same literature exploits variation across local labor markets (Autor et al., 2013, 2016; Acemoglu et al., 2016). However, for reasons that will be explained later in the paper, we opted for the industry-level analysis.

${ }^{9}$ Similarly, Castellares (2015) also finds evidence of the quality-upgrading strategy in the apparel industry. He finds that more productive firms use more expensive intermediate inputs to produce higher-quality goods.
}

\section{PUCP}


formal labor. In Vietnam, McCaig and Pavcnik (2015) explore the transitions between formal and informal employment by worker characteristics as the country developed. They find that less-educated workers (who are more likely to be older and female) are less likely to transition into formalization, while the more educated (mainly younger male workers) are more likely to move from the informal to the formal sector. In Peru itself and using the same data (ENAHO), Cisneros-Acevedo (2021) identifies two margins of informality-workers in unregistered firms (extensive margin) and workers in registered firms that are not complying with labor laws (intensive margin) - and finds that while trade liberalization increases the likelihood of being hired as an "undeclared" worker by a registered firm, they also reduce informality by pushing unregistered, less efficient firms out of the market. When combined, the former effect prevails. Despite differences in the definition of informality used in her work relative to ours, our results are still consistent with hers in the aggregate: informality still rises as the impact from formal firms that hire more workers "off-the-books" prevails. ${ }^{10}$

The paper is organized as follows. Section 2 provides an overview of the main trends and characteristics of the manufacturing sector and important labor reforms in Peru, mainly over the past decade, and of the importance that China has gained as an import provider for Peruvian markets. Section 3 discusses the methodology used for the econometric analysis of the impact and presents the key features of the data on labor and informality. Section 4 reports the results from the estimations and Section 5 concludes.

\section{The Peruvian Manufacturng Sector and the Presence of Chinese Manu- facturing Imports}

This section provides details on both the evolution - and growth - of the Peruvian manufacturing sector and the surge of imports from China since the early 2000s.

\subsection{The Manufacturing Sector in Peru}

Although the manufacturing sector is not as predominant in the Peruvian economy as it is in other Latin American countries, it remains a nontrivial source of output and employment. ${ }^{11}$ On average, it represented $16 \%$ of the country's GDP in 2001-2010 and concentrated $10.5 \%$ of the labor force in 2008-2012. ${ }^{12}$ Looking at the sector's evolution during the 2000s, although there was a slowdown after the financial crisis toward the end of the decade, both output and labor expanded steadily throughout (Figure 1). The expansion in the number of workers in the manufacturing sector is particularly remarkable. In absolute terms, the labor force in the

\footnotetext{
${ }^{10}$ Other papers also analyze both margins of informality to design formalization policies. For instance, Ulysea (2020) finds that policies that address informality are more effective when focused on increasing the enforcement on the extensive margin, which generates gains in total factor productivity (TFP) and output, without increasing unemployment.

${ }^{11}$ Based on information from the World Development Indicators, the average value-added of the manufacturing sector as a share of GDP over 2001-2010 was slightly higher in Peru (16\%) than the average for Latin America during the same period $(15 \%)$.

${ }^{12}$ The sources of these figures are the Peruvian Central Bank (BCRP) and the National Institute of Statistics (INEI), respectively.
} 


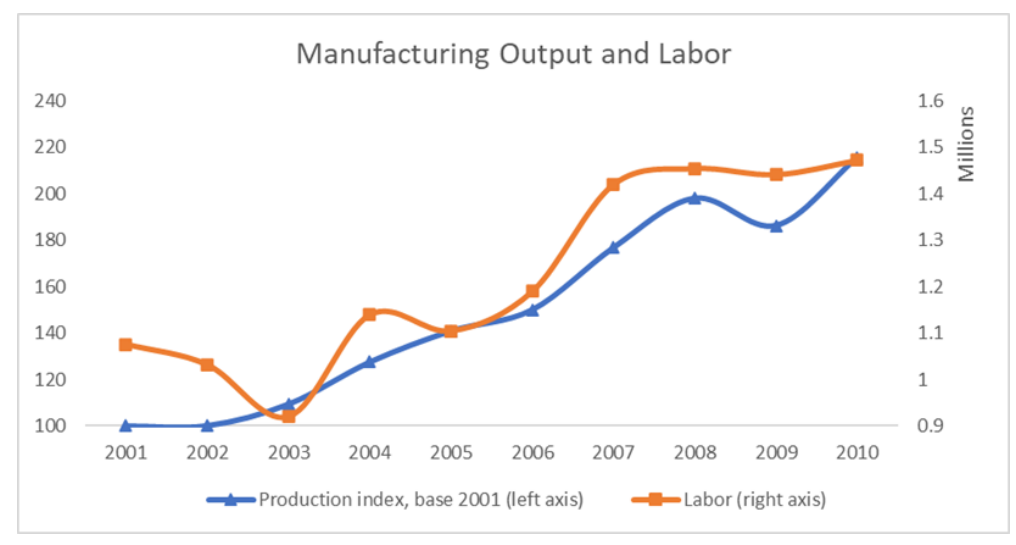

Note: Total manufacturing labor includes formal and informal employment. Source: Compiled by the authors based on INEI and ENAHO.

Figure 1. Manufacturing output and labor in Peru, 2001-2010.

manufacturing sector grew 37\% between 2001 and 2010, after only growing $1 \%$ in the previous decade. The expansion in the labor force in the manufacturing sector was also substantial in relative terms - labor in services increased only $10 \%$ and labor in agriculture even decreased $22 \%$ over the same period. ${ }^{13}$

Within the Peruvian manufacturing sector, the largest industries in terms of their contribution to the sector's total value-added are those related to metals, minerals, and apparel, in descending order. Together, they accounted for over a third of the country's manufacturing output during 2007-2010. They are followed by industries such as food, chemicals, and textiles.

In terms of employment, the manufacturing labor force was 1.2 million workers on average in 2001-2010 and was heavily concentrated in a few industries. Over two-thirds of the workers in the sector were employed in four industries: textiles and apparel combined accounted for almost $32 \%$ of the labor force, followed by food and furniture with $22 \%$ and $13 \%$, respectively.

Besides its high concentration, the other outstanding feature of the manufacturing labor force in Peru is that most workers operate in the informal sector. ${ }^{14}$ Peru has one of the highest rates of informality in Latin America (OECD/CIAT/IDB, 2016). Although the share of workers with informal jobs has slightly decreased in the last years, Figure 2a shows that $79 \%$ of the manufacturing jobs are still informal, despite important measures taken by the government to address informality. ${ }^{15}$ Figure $2 \mathrm{~b}$ shows that formal and informal jobs in manufacturing grew

\footnotetext{
${ }^{13}$ Figures based on World Development Indicators.

${ }^{14}$ As stated previously, a worker is defined as being informal if they do not contribute to the social security system, regardless of the status of the firm that employs them (i.e., formal vs. informal establishments).

${ }^{15}$ The measures were the Promotion and Formalization of Micro and Small Enterprises (SME) Act in 2003 which aimed to increase formal job hiring among micro and small firms by reducing hiring labor costs - and the electronic payroll system by the National Superintendent of Tax Administration (SUNAT) and the Ministry of Labor and Employment Promotion Office in 2006 - which enforced the report of payrolls (including information on workers, wages, contract type and other benefits) and aimed at a better accounting of formal labor in formal firms. According to Chacaltana (2017) neither of the measures had a significant impact reducing informality or hiring labor costs.
} 


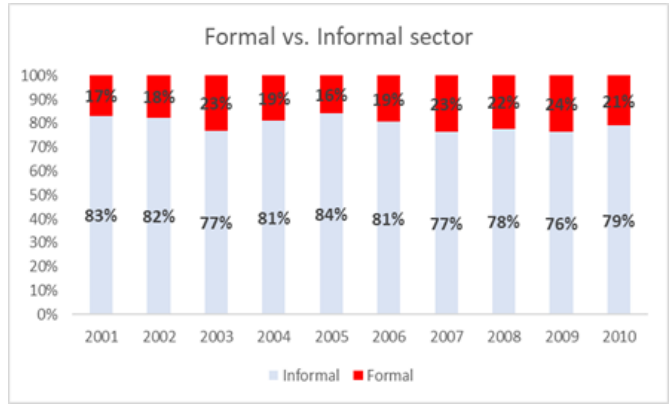

(a) Share of workers.

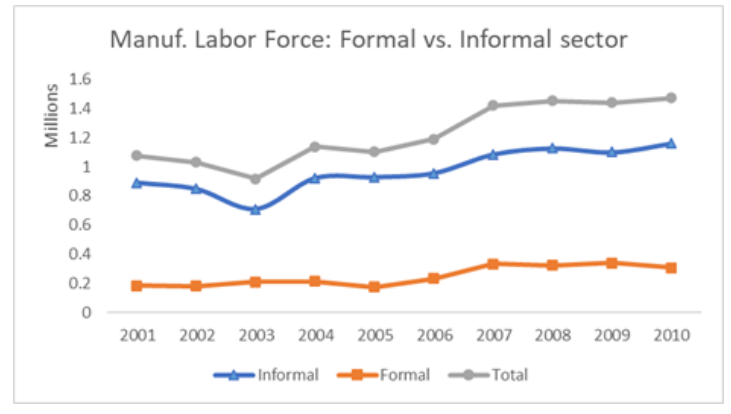

(b) Number of workers.

Source: Compiled by the authors based on ENAHO.

Figure 2. Manufacturing labor force, formal vs. informal sector 2001-2010.

Table 1

Share of informal workers by industry, 2001-2010.

\begin{tabular}{lccc}
\hline \multicolumn{1}{c}{ Sector } & $\begin{array}{c}\text { Informality } \\
\text { share } 2001\end{array}$ & $\begin{array}{c}\text { Informality } \\
\text { share } 2010\end{array}$ & $\begin{array}{c}\text { Change } \\
2001-2010\end{array}$ \\
\hline Furniture and manufacturing n.e.c. & $96 \%$ & $92 \%$ & $-3.88 \%$ \\
Leather and footwear & $93 \%$ & $92 \%$ & $-1.51 \%$ \\
Radio, TV, optical inst & $100 \%$ & $91 \%$ & $-9.27 \%$ \\
Textiles & $86 \%$ & $89 \%$ & $3.30 \%$ \\
Wood products & $94 \%$ & $89 \%$ & $-5.47 \%$ \\
Apparel & $90 \%$ & $83 \%$ & $-7.73 \%$ \\
Metal products, except m\&e & $84 \%$ & $81 \%$ & $-3.14 \%$ \\
Non-metallic products & $88 \%$ & $79 \%$ & $-10.42 \%$ \\
Motor vehicles and transport equip, TV & $51 \%$ & $78 \%$ & $54.52 \%$ \\
Publishing and printing & $63 \%$ & $73 \%$ & $17.12 \%$ \\
Food, beverages and Tobacco & $74 \%$ & $73 \%$ & $-1.77 \%$ \\
M \& E, \& office \& computing & $71 \%$ & $63 \%$ & $-11.77 \%$ \\
Paper and paper products & $46 \%$ & $57 \%$ & $21.84 \%$ \\
Electrical machinery & $71 \%$ & $44 \%$ & $-37.47 \%$ \\
Rubber and plastics & $40 \%$ & $43 \%$ & $7.85 \%$ \\
Basic metals & $36 \%$ & $38 \%$ & $6.67 \%$ \\
Chemicals & $58 \%$ & $30 \%$ & $-48.89 \%$ \\
\hline
\end{tabular}

Source: Authors' calculations based on ENAHO.

during the past decade, although the formal sector expanded at a faster pace until the financial crisis and contracted slightly after.

Informality permeates all industries in the manufacturing sector, but its intensity varies by industry. Table 1 shows that in 2010, industries such as furniture, leather and footwear, textiles, apparel and wood-some of them labor-intensive - had the highest participation of informal workers, with levels above $80 \%$. In contrast, basic metals and chemicals registered levels below $40 \%$. With respect to changes in the presence of informal workers within industries, between 2001 and 2010, informality intensified in industries such as motor vehicles, paper, and printing products. Coincidentally, these sectors also experienced a significant increase in the presence of Chinese imports during the same period. 


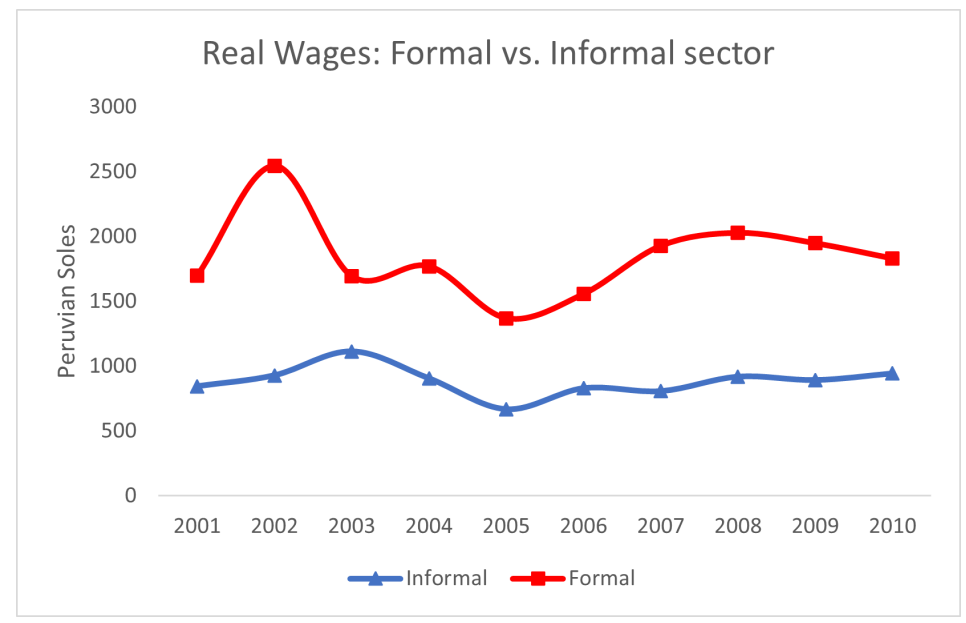

Source: Compiled by the authors based on ENAHO.

Figure 3. Manufacturing real monthly wages, formal vs. informal, 2001-2010.

Table 2

Real average monthly wages by industry, 2001-2010.

\begin{tabular}{lccc}
\hline \multicolumn{1}{c}{ Sector } & 2001 (US dollars) & 2010 (US dollars) & Change 2001-2010 \\
\hline Publishing and printing & 747.7 & 416.1 & $-44.4 \%$ \\
Rubber and plastics & 667.3 & 405.0 & $-39.3 \%$ \\
Textiles & 182.3 & 137.2 & $-24.7 \%$ \\
Motor vehicles and transport equip, TV & 592.0 & 474.7 & $-19.8 \%$ \\
Leather and footwear & 603.0 & 568.8 & $-5.7 \%$ \\
M \& E, \& office \& computing & 344.7 & 335.1 & $-2.8 \%$ \\
Apparel & 230.7 & 266.6 & $15.6 \%$ \\
Non-metallic products & 338.5 & 396.1 & $17.0 \%$ \\
Food, beverages and Tobacco & 271.3 & 347.7 & $28.2 \%$ \\
Metal products, except m\&e & 479.0 & 619.8 & $29.4 \%$ \\
Furniture and manufacturing n.e.c. & 813.3 & 1138.9 & $40.0 \%$ \\
Electrical machinery & 383.9 & 543.7 & $41.6 \%$ \\
Chemicals & 242.6 & 344.5 & $42.0 \%$ \\
Paper and paper products & 449.4 & 694.3 & $54.5 \%$ \\
Radio, TV, optical inst & 219.5 & 417.3 & $90.1 \%$ \\
Basic metals & 609.9 & 1228.1 & $101.4 \%$ \\
Wood products & 141.1 & 356.6 & $152.7 \%$ \\
Coke and petroleum & 309.1 & 2420.9 & $683.3 \%$ \\
\hline
\end{tabular}

Note: Wages are averages across workers by industry and year.

Source: Authors' calculations based on ENAHO.

Finally, real average wages in both formal and informal sectors grew, albeit modestly, in tandem with the growth in the labor force over 2001-2010. Comparing the values from 2010 to those in 2001, we observe that wages for formal and informal jobs grew $8 \%$ and $12 \%$, respectively (Figure 3). However, there are major variations across industries. Table 2 reveals that workers in the wood, basic metals, and radio and TV industries - some of them with a high share of formal labor - saw their overall real salaries improve while the largest drops in wages were observed in publishing and printing, rubber and plastic and textiles. 


\subsection{The Rise of China as the Main Import Provider for Peru}

As the manufacturing sector expanded over 2001-2010, so did the inflow of Chinese goods as a share of Peruvian manufacturing imports, which multiplied almost 15 times over the period. This variation is remarkable for two different reasons (see Figure 4). First, the increase of Chinese imports during the 2000s was notoriously higher than the one observed in imports from the rest of the world, which only multiplied fourfold over the same period. Second, although imports from China started growing in the late 1990s, the surge became noteworthy in the early 2000s (around the time of China's entry to the WTO) and grew steadily throughout the 2000s. Focusing the study of the impact of the surge in import competition from China in Peru in 2001-2010, thus, seems to be an appropriate choice timewise.

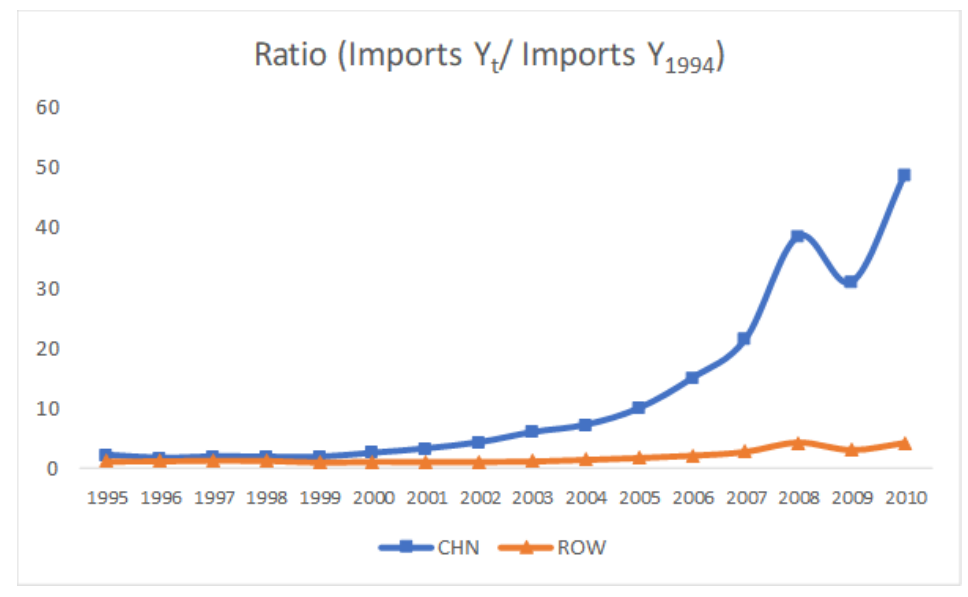

Source: Compiled by the authors based on INEI and COMTRADE.

Figure 4. Import Growth: China vs. Rest of the World, 1995-2011.

To capture the exposure of Peruvian domestic markets to Chinese imports, an import penetration (IP) index is calculated as follows:

$$
I P_{P e r u, j t}=\frac{M_{j t}^{\text {China }}}{P_{j t}+M_{j t}^{\text {World }}},
$$

where $I P_{j t}$ is the import penetration in industry $j$ and year $t, P_{j t}$ corresponds to the values of domestic production in industry $j$ and year $t$, and $M_{j t}$ is the total value of imported goods from either China, the rest of the world (ROW), or worldwide in industry $j$ and year $t$. Figure 5 shows the import exposure variable as described above and the share of Chinese imports over the total of manufacturing imports. ${ }^{16}$ Both measures increased significantly over time. The Chinese import share went from $5.9 \%$ in 2001 to $20.1 \%$ in 2010; meanwhile, the import exposure was $2.5 \%$ in 2001 and $10.8 \%$ in 2010 .

\footnotetext{
${ }^{16}$ The share of Chinese imports corresponds to $M_{-}$share ${ }_{P e r u, j t}=\frac{M_{j t}^{\text {China }}}{M_{j t}^{\text {World }}}$ and does not control for the domestic production of industry $j$ in time $t$.
} 


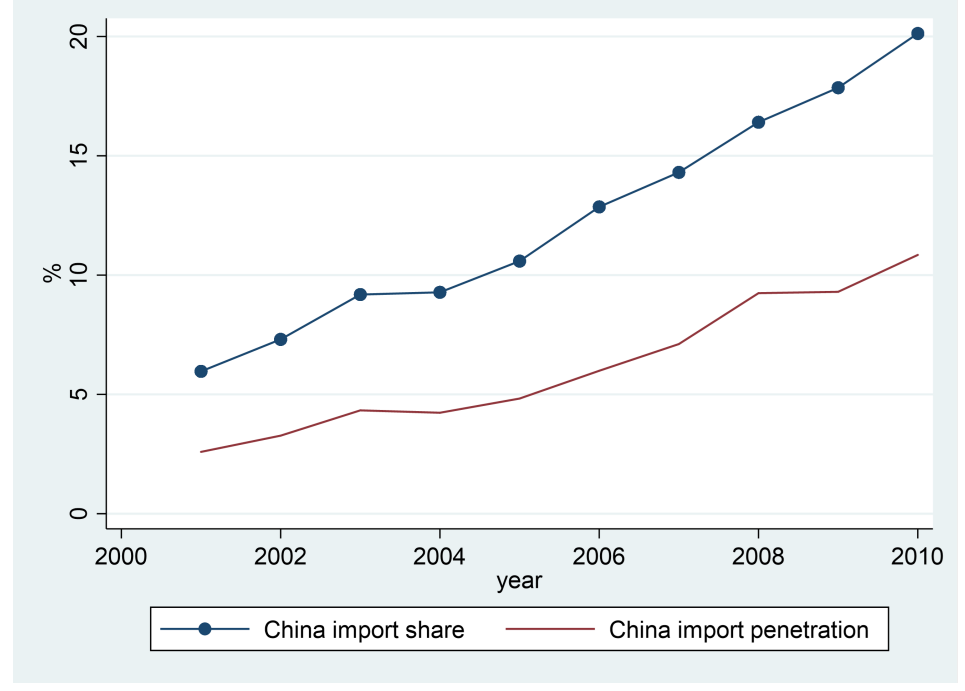

Note: The manufacturing sector comprises sectors 15-36 in ISIC Rev. 3.

Source: Compiled by the authors based on INEI and COMTRADE.

Figure 5. Chinese Presence in the Peruvian total manufacturing sector, 2000-2010.

Table 3

Main import trade partner by industry, 2000 vs. 2010.

\begin{tabular}{lcc}
\hline \multicolumn{1}{c}{ Sector } & 2000 & 2010 \\
\hline Food, beverages and Tobacco & United States & Argentina \\
Textiles & South Korea & China \\
Apparel & China & China \\
Leather and footwear & China & China \\
Wood products & Chile & Chile \\
Paper and paper products & Chile & Chile \\
Publishing and printing & United States & United States \\
Coke and petroleum & Nigeria & United States \\
Chemicals & United States & United States \\
Rubber and plastics & United States & China \\
Non-metallic products & United States & China \\
Basic metals & Venezuela & China \\
Metal products, except m\&e & United States & China \\
M \& E, \& office \& computing & United States & China \\
Electrical machinery & United States & China \\
Radio, TV, optical inst & United States & China \\
Motor vehicles and transport equip, TV & Japan & Japan \\
Furniture and manufacturing n.e.c. & China & China \\
\hline
\end{tabular}

Source: Authors' calculations based on COMTRADE.

The rise of China as the main import provider for Peru is also evident when we break down the analysis by industry. On the one hand, Table 3 shows that 10 out of the 18 industries in our sample had a different main provider in 2010 relative to 2001 and that China became Peru's main supplier in 8 out of these 10 industries. For instance, industries relating to computing machinery, electrical machinery, radio and TV products, rubber and plastic, metals, and nonmetallic minerals were mainly supplied by the US in 2001. In contrast, in 2010, these industries reported 
China as their main supplier. Furthermore, China gained importance as the main supplier during a period when the number of Peruvian trade partners in the manufacturing sector increased substantially. ${ }^{17}$

On the other hand, in terms of sheer Chinese presence by industry, Table 4 shows that apparel, leather, and furniture - industries with a very high share of informality - were the three industries with the largest exposure to Chinese competition in 2010, with indexes of above $50 \%$. Other industries with indexes above $40 \%$ are textiles; radio, TV, and optical instruments; and nonmetallic products. However, in terms of changes in exposure to competition between 2001 and 2010, China's presence intensified in almost all manufacturing industries, especially in basic metals, motor vehicles and paper.

In sum, not only the exposure to Chinese imported products increased drastically during the period analyzed, but also China has become one of the most relevant players in the Peruvian market. Despite having a greater number of trading partners in the various industries, China has managed to capture significant market share and position itself as Peru's main supplier, ahead of other key partners such as the United States.

Table 4

Chinese Import exposure in Peru by industry (\%), 2001 vs. 2010.

\begin{tabular}{lccc}
\hline \multicolumn{1}{c}{ Sector } & 2001 & 2010 & Change 2001-2010 \\
\hline Basic metals & 0.7 & 25.3 & $3434.7 \%$ \\
Paper and paper products & 0.4 & 5.4 & $1317.1 \%$ \\
Motor vehicles and transport equip, TV & 1.8 & 15.4 & $760.3 \%$ \\
Publishing and printing & 1.7 & 9.3 & $435.6 \%$ \\
Radio, TV, optical inst & 7.9 & 41.1 & $418.1 \%$ \\
Food, beverages and Tobacco & 0.3 & 1.5 & $398.9 \%$ \\
M \& E, \& office \& computing & 5.4 & 24.3 & $353.4 \%$ \\
Electrical machinery & 5.5 & 21.0 & $284.0 \%$ \\
Non-metallic products & 11.0 & 41.0 & $272.0 \%$ \\
Chemicals & 2.7 & 9.4 & $252.4 \%$ \\
Metal products, except m\&e & 8.3 & 25.0 & $202.1 \%$ \\
Wood products & 3.1 & 7.7 & $143.5 \%$ \\
Rubber and plastics & 9.9 & 21.4 & $115.5 \%$ \\
Textiles & 21.0 & 42.8 & $104.1 \%$ \\
Leather and footwear & 38.6 & 66.2 & $71.7 \%$ \\
Furniture and manufacturing n.e.c. & 32.8 & 50.3 & $53.6 \%$ \\
Apparel & 52.5 & 74.1 & $41.1 \%$ \\
Coke and petroleum & 9.9 & 1.0 & $-90.1 \%$ \\
\hline Source: Authors' calculations based on INEI and COMTRADE. & \\
\hline
\end{tabular}

\section{Empirical Methodology and Data}

Having described the expansion of the manufacturing sector and established the growing importance of Chinese imports in the Peruvian market in the 2000s, this section discusses the data and the methodology used to assess the surge's impact.

\footnotetext{
${ }^{17}$ The average number of trade partners by industry escalated from 58 to 83 in $2000-2010$ based on COMTRADE.
} 


\subsection{Empirical Methodology}

The empirical strategy follows Paz (2014), who studies the effect of tariff reductions on the share of informal manufacturing employment and wages in Brazil in 1989-2001. ${ }^{18}$ This methodology consists of estimating the effect of growing Chinese import competition in Peru on two labor market outcomes: a) the probability of having an informal job and b) real monthly salaries of formal and informal jobs. The model is specified as follows:

$$
y_{i j t}=\beta_{0}+\beta_{1} I P_{P e r u, j t}+\alpha * \boldsymbol{X}_{i j t}+\beta_{2} * \text { size } i t+\delta_{t}+\delta_{j}+e_{i j t},
$$

where $y_{i j t}$ corresponds to the outcome variable for worker $i$ in industry $j$, and year $t$. The first outcome of interest is a binary variable that takes the value of 1 if the worker has an informal job and 0 otherwise. ${ }^{19}$ We define an informal job following Támola (2014), who determines informality based on those jobs where the worker reports paying for the social security system in Peru. ${ }^{20}$ Our definition considers information from the primary occupation of all employees (older than 14 years old according to Peru's definition) regardless of their job affiliation (self-employers, employee, domestic workers, public employers, family workers and all employed workers). ${ }^{21}$ The second outcome is the individual real monthly wage, distinguishing whether the worker is employed formally or informally. ${ }^{22}$

As explanatory variables, we consider both industry- and worker-level variables. At the industry level, the main variable of interest for our analysis is $I P_{j t}$, which refers to the index of exposure to Chinese imports, explained in the previous section. At the individual level, we control for worker characteristics such as age, gender, marital status, degree of education and region of residence, denoted by the matrix $X_{i j t}$. We also include size $e_{i t}$, which denotes the size of the firm in which the individual works. ${ }^{23}$ Finally, $\delta_{t}$ and $\delta_{j}$ refer to the fixed effects per year $(t)$

\footnotetext{
${ }^{18}$ Originally, the intention was to follow the methodology in Autor et al. (2013) to exploit geographical variation. However, the employment shares that could be used as instruments following their methodology were heavily concentrated on a few local markets (provinces) in Peru. This would have introduced biases in the overall estimates (see Goldsmith-Pinkham et al., 2018, for a discussion on the plausibility of the research design implied with the use of the Bartik instruments).

${ }^{19}$ As stated previously, a worker is defined as being informal if they do not contribute to the social security system, regardless of the status of the firm that employs them (i.e., formal vs. informal establishments).

${ }^{20}$ The author makes a recompilation of formality definition in different countries in LAC and defines informality based on the reports of social security system for Peru.

${ }^{21}$ This information is taken from a dichotomic variable that is 1 if (i) the individual is occupied (question ocu500 in ENAHO survey = Occupied) and if the individual reported positive payments to social security (in Soles) (question P524B1) in the ENAHO module 500 related to employment and income. See https://www.inei. gob.pe/media/MenuRecursivo/metodologias/empleo01.pdf for further information related to the classification of the economically active population in Peru.

${ }^{22}$ The nominal wages are converted to 2011 real prices using Peru's consumer price index.

${ }^{23}$ The firm's size is a self-reported variable included in the ENAHO. Firms' size is controlled for using dummies defined based on the number of workers in the following categories: small-less than 6 workers; medium-6 to 50 workers; and large - more than 50 employees. We acknowledge the existing potential bias that self-reporting may introduce in the results. To assess the extent of this concern, we conducted a robustness exercise where we use the continuous form for firm size- we used the natural logarithm of the number of employees. The results did not change in magnitude and remained statistically significant. For simplicity of interpretation, we only report the results using the dummy variable for size, however, the other results are also available upon request.
} 
and industry $(j)$, respectively.

The model in (2) poses some econometric challenges that need to be addressed to avoid potential inconsistency and bias in the estimates.

First, as discussed in previous studies (Paz, 2014; Mion and Zhu, 2013; and Autor et al., 2013), there is potential endogeneity between the IP index $\left(I P_{j t}\right)$ and the dependent variable in $(2)$, to the extent that both variables might be positively correlated with unobserved shocks to Peruvian demand. Since the objective of this paper is to study how increasing import competition from China emerging from supply-driven factors affected the labor market in Peru, we need to purge the import penetration measure from other potential demand-driven shocks. For this purpose, we take an instrumental variable approach and use Chilean exposure to imports from China as an instrument. The choice of Chilean imports from China as an instrument is based on the following criteria: a) the import structure in Chile bears strong resemblance to that of Peru and b) the trade relationship between the two countries was modest during the period of analysis, therefore, trade-related effects induced by Chinese competition in Chilean markets could be considered to be independent from domestic shocks that may have affected Peruvian labor outcomes. ${ }^{24,25}$

Additionally, the possible presence of reverse causality between labor market outcome variables and the Chinese import penetration index is a concern. For instance, industries with a higher share of informal workers (a situation which is associated with lower labor costs) might be competitive enough in the domestic market and thus face lower demand for imported goods from China, which are also less expensive. This reverse causality concern is mitigated by the simultaneous use of outcome variables at the individual level and variables of interest at the industry level. As a worker-level decision is less likely to influence the aggregate industry-level variable of interest, potential reverse causality is less concerning. ${ }^{26}$ In addition, as import penetration could also be correlated with unobserved industry characteristics, we will also use industry fixed effects to address this potential bias. ${ }^{27}$

Finally, Paz (2014) also discusses the presence of simultaneity between having an informal job and the wage reported by the worker. We follow his strategy to address this concern and use the estimates from the analysis of the probability of having a job in the informal sector as the first step in the two-step estimation process where we control for selection bias.

\footnotetext{
${ }^{24}$ In the 2000s, the average annual share of Chilean imported goods in Peru's total manufacturing imports was $5 \%$. On the export side, exports to Chile did not exceed 3\% of Peru's total exports. Given that Colombia is the other South American country with similar characteristics to Chile vis-à-vis Peru, we also experimented using Colombia data as an alternative instrument. Unfortunately, the instrument with Colombian data did not pass the statistical tests to assess its quality and, thus, we only present the results using the instrument with Chilean data.

${ }^{25} \mathrm{Paz}$ (2014) uses Colombian import-tariff information as an instrument for the Brazilian trade liberalization process. In keeping with the criteria that we describe above, he evaluated similarities between the trade liberalization process that both countries underwent and the commercial ties between them, which was small relative to other partners.

${ }^{26}$ Ebenstein et al. (2014) present a similar argument on the reverse causality between industry-level trade variables and individual-level characteristics for their analysis of the US.

${ }^{27}$ See Goldberg and Pavcnik (2005) for a more detailed discussion of this type of simultaneity bias. It is also worth noting that as the individuals are not followed over time - the analysis is performed over a repeated cross-section-individual-level fixed effects cannot be included.
} 
Thus, we estimate the worker-level probability of having an informal job as described below:

$$
\text { informal }_{i j t}=\beta_{0}+\beta_{1} I P_{\text {Peru }, j t}+\beta_{2} * \text { size }_{i t}+\alpha * \boldsymbol{X}_{i j t}+\beta_{3} * \text { other }_{i t}+\delta_{t}+\delta_{j}+e_{i j t},
$$

where we include a variable other $_{i t}$ that is related to the individual decision to have an informal job but is not correlated with the salary that the individual receives. The "other" variable that we employ for this purpose is the current job situation of other family members in the household. Specifically, we consider whether the household reports that one of its members is being subemployed or unemployed. ${ }^{28,29}$

Once we estimate the first stage, we compute the inverse Mills ratio using the predicted values for informality. We use the ratio as a variable in the second stage to control for potential worker self-selection in the earning equations. The wage equations are described in (4) and (5) for the formal and informal workers, respectively.

$$
\begin{aligned}
& \log \left(\text { wage }^{\text {formal }}\right)_{i j t}=\varphi_{0}{ }^{\text {for }}+\varphi_{1}{ }^{\text {for }} I P_{P e r u, j t}+\alpha^{\text {for }} * \boldsymbol{X}_{i j t}+\varphi_{2}{ }^{\text {for }} * \operatorname{size}_{i j t}+\delta_{t}{ }^{\text {for }}+\delta_{j}{ }^{\text {for }}+ \\
& \theta_{\varepsilon, v 1}^{\text {for }}\left(\overline{\text { inform }} a_{i j t}\right)+v_{1 i j t} \\
& \log \left(\text { wage }^{\text {informal }}\right)_{i j t}=\varphi_{0}{ }^{i n f}+\varphi_{1}^{i n f} I P_{P e r u, j t}+\alpha^{i n f} * \boldsymbol{X}_{i j t}+\varphi_{2}{ }^{i n f} * s i z e_{i j t}+\delta_{t}^{i n f}+\delta_{j}^{i n f}+ \\
& \theta_{\varepsilon, v 2}^{\text {inf }}\left(\text { inform }_{a_{i j t}}\right)+v_{2 i j t} \text {, }
\end{aligned}
$$

where, $\theta_{\varepsilon, v 1}^{f o r}$ and $\theta_{\varepsilon, v 2}^{i n f}$ capture the potential correlation between the error term and selfselection into participating in the formal or informal sector, respectively. If we ignore these components, the estimates for the impact of Chinese import penetration on wages could be biased. ${ }^{30}$ We also corrected the standard errors obtained from equations (4) and (5) through a 1010-repetition bootstrap maintaining the original sample weights for each of the subsamples. Without this correction, the standard errors in our statistical tests would be biased. ${ }^{31}$

Finally, we follow the literature and explore the heterogeneity in the impact of the surge. We estimate the equations in (3) to (5) by workers' education level. We include four education categories: a) no education at all, b) elementary education (complete or not), c) high-school education (complete or not), and d) college education (complete or not).

\subsection{Data Description}

First, as mentioned above, the worker-level variables used to observe labor outcomes come from the Peru's household survey (ENAHO) for 2001-2010. ENAHO provides information on the

\footnotetext{
${ }^{28}$ According to the Peruvian household survey, a worker is considered subemployed if they work 30 hours or less per week but are willing to work more hours.

${ }^{29} \mathrm{Paz}$ (2014) also uses the employment status of another member of the household - in this case, whether the household reports that another of its members is employed in the formal sector. We do not use this variable in our analysis as it would lead to the loss of a considerable number of observations.

${ }^{30}$ If $\theta_{\varepsilon, v 1}^{f o r}$ and $\theta_{\varepsilon, v 2}^{i n f}$ are statistically significant in the second stage, the evidence would suggest a correlation between the error terms and the importance of controlling for these components.

${ }^{31}$ See Araujo et al. (2016) for more information on the use of 1010 bootstrap repetitions to correct standard errors.
} 
Table 5

Summary statistics.

\begin{tabular}{|c|c|c|c|c|c|c|c|}
\hline Education level & $\begin{array}{l}\text { Number of } \\
\text { observations }\end{array}$ & $\begin{array}{c}\text { Total } \\
\text { Labor } \\
\text { Force }(\%)\end{array}$ & $\begin{array}{c}\text { Informal } \\
\text { Labor } \\
\text { Force }(\%)\end{array}$ & $\begin{array}{c}\text { Formal } \\
\text { Labor } \\
\text { Force }(\%)\end{array}$ & $\begin{array}{c}\text { Informality } \\
(\%)\end{array}$ & $\begin{array}{c}\text { Average } \\
\text { monthly wages, } \\
\text { informal (USD) }\end{array}$ & $\begin{array}{c}\text { Average } \\
\text { monthly wages, } \\
\text { formal (USD) }\end{array}$ \\
\hline No education & 442,240 & $3 \%$ & $4 \%$ & $1 \%$ & $97 \%$ & 52.3 & 321.0 \\
\hline Elementary & $2,420,077$ & $19 \%$ & $21 \%$ & $8 \%$ & $92 \%$ & 123.4 & 379.6 \\
\hline High School & $6,790,725$ & $52 \%$ & $53 \%$ & $47 \%$ & $82 \%$ & 203.1 & 402.6 \\
\hline College & $3,382,508$ & $26 \%$ & $21 \%$ & $45 \%$ & $67 \%$ & 304.6 & 730.7 \\
\hline Total & $13,035,550$ & $100 \%$ & $100 \%$ & $100 \%$ & $81 \%$ & 198.6 & 545.8 \\
\hline
\end{tabular}

industry in which each respondent works. This information is available at the ISIC Rev. 3 4-digit level; however, to define an industry for our analysis, we aggregated the count of respondents at the 2-digit-level. ${ }^{32}$ ENAHO provides a rich set of worker-level variables and allows us to control for observable individual characteristics such as gender, age, marital status, level of education, and geographic location, among others.

Table 5 shows summary statistics by workers' education level. We observe that individuals with high-school education represent the largest share of workers in the sample, accounting for $52 \%$ of the labor force in manufacturing during the period studied. Then, workers with college education, workers with elementary education, and workers with no education follow with $26 \%$, $19 \%$, and $3 \%$ of the labor force in the manufacturing sector, respectively. Workers with high school education are the largest group in both informal and formal sectors. However, while they are by far the most prominent group in the informal sector (53\%), followed by college (22\%) and elementary (21\%); they are only slightly larger in the formal sector $(47 \%)$, followed closely by workers with college education $(45 \%)$. Regarding the two main types of outcome variable, we note that informality is high across education groups, however, it decreases with the education level. Meanwhile, regarding earnings, we observe that real monthly wages increase with worker's education, although the difference in wages by educational group is larger among formal jobs relative to informal jobs. Finally, we also observe that as expected, formal jobs pay wages that are substantially larger (on average three times larger) than those in informal jobs.

Second, the trade-related information needed to build the variables that capture exposure to Chinese manufacturing goods and export trends is taken from the UN COMTRADE database for 2001-2010. ${ }^{33}$ The domestic production data comes from the Peruvian National Institute of Statistics (Instituto Nacional de Estadística e Informática, INEI) in local currency (INEI, 2012). The domestic production data for Chile is taken from the country's National Industrial Survey (Encuesta Nacional Industrial Anual, ENIA). Given that the data on domestic production

\footnotetext{
${ }^{32}$ The industrial activities considered in the sample fall between ISIC Rev. 3 classes 1500 and 3699 . The purpose of aggregating to the 2-digit level is to have enough observations per industry while preserving a certain degree of variation across groups.

${ }^{33}$ Although the trade data in COMTRADE is originally presented in HS codes, we downloaded such data from WITS, already converted to ISIC codes. We do this to simplify the merging of databases, given that the other dataset that we use - domestic production from ENAHO - is only available in ISIC-like codes. However, the correspondence table between HS and ISIC can be found in WITS portal: https://wits.worldbank.org/product_ concordance.html.
} 
as presented in INEI follows a local industry classification that is slightly different to ISIC Rev. 3 (the groupings differ for some industries), we adjusted all the variables from the sources mentioned above such that they follow the classification used by INEI. That yields 18 industries in total. The details of the concordance between the classifications can be found in Appendix A. Finally, the IP index is calculated in local currency to mitigate the impact of exchange-rate devaluations. ${ }^{34}$

Also, we account for the strong domestic growth experienced due to the structural reforms implemented in the Peruvian economy and some specific industry-year shocks, such as the FTA with the United States, which was also negotiated and implemented during the 2000s, using an industry-level growth variable in some specifications. ${ }^{35}$ This variable accounts for the average growth rate for domestic production in each industry over 2001-2010 and is created based on information from the INEI at the industry level.

A preliminary correlation analysis between Chinese import exposure in Peru and the outcomes of interest suggests that more competition from China in manufacturing is associated with higher shares of informality (Figure 6). Meanwhile, Figure 7 reveals that more competition from China might be associated with lower real wages in the manufacturing sector. A robust analysis of these relationships follows.

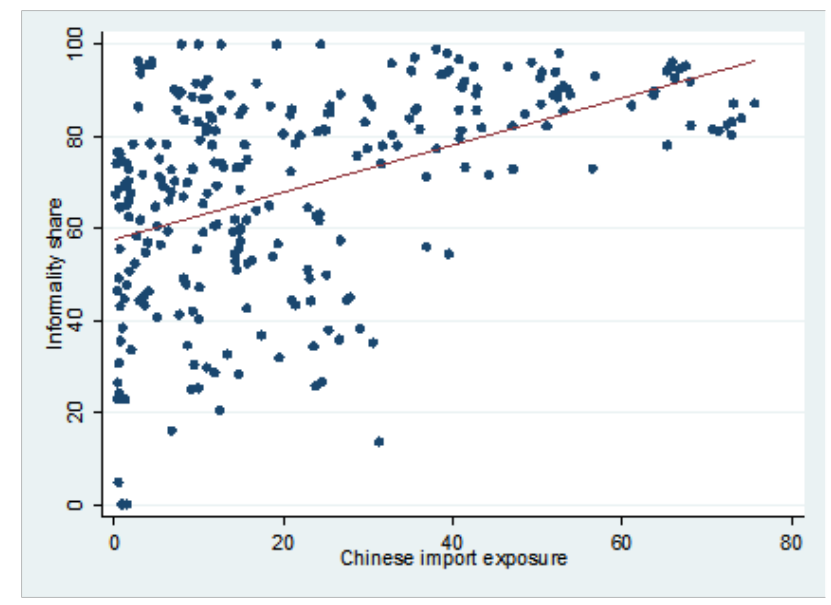

Note: The unit in the graph represents the informality share in an industry-year, the industry is defined as 2-digits ISIC rev. 3 in categories 15 to 36 .

Source: Authors' calculations based on ENAHO, INEI, and COMTRADE.

Figure 6. Correlation between informality share and the Chinese import exposure by industry within manufacturing sector.

\footnotetext{
${ }^{34}$ In the event of a devaluation, the import penetration index increases because of currency adjustments, even though this might not be directly related to a real increase in imports. To address this issue, we use the real effective exchange rate (REER) reported by the IMF-IFS to build a nominal exchange rate that keeps the REER constant over 2001-2011. This exchange rate is employed to convert imports from USD to local currency.

${ }^{35}$ For instance, in response to the negotiation talks for the USA-Peru FTA which started during the first half of the 2000s, firms in some industries may have updated their production decisions and thus altered possible outcomes such as the number of informal/formal workers hired and their monthly remunerations.
} 


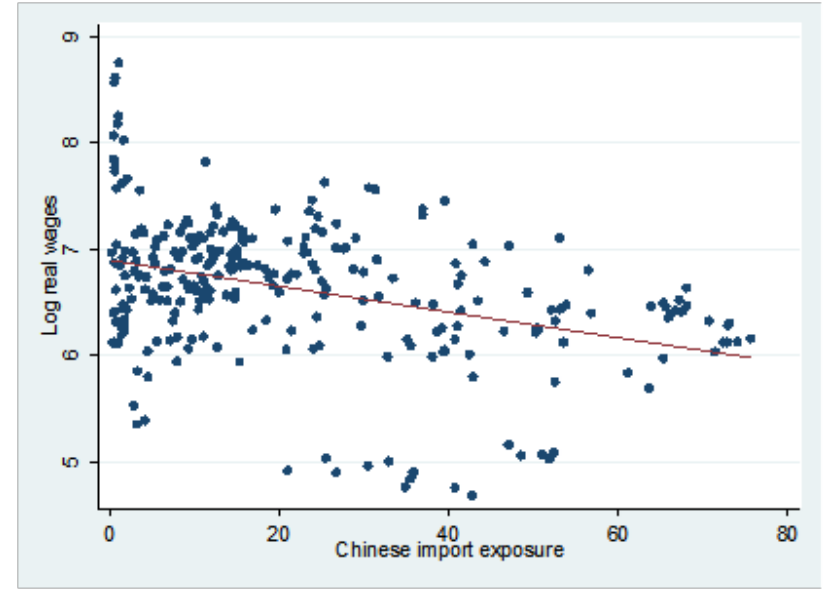

Note: The unit in the graph represents the share of informality in an industry-year. The industry is defined at the 2-digit level and comprises categories 15 to 36 in ISIC Rev. 3.

Source: Authors' calculations based on ENAHO, INEI, and COMTRADE.

Figure 7. Correlation between log real wages and Chinese import exposure within manufacturing sector.

\section{Estimation Results}

We first estimate the effect of import competition from China on the likelihood of having an informal job. Then, we evaluate the impact on formal and informal wages. Finally, we conduct further analysis accounting for the presence of self-employed workers in the estimations.

\subsection{Probability of Having an Informal Job}

Table 6 presents the results from estimating Eq. (3). Columns (1) to (3) show the results considering the overall China's IP index. Each column reflects the results using a different technique: we use OLS in column (1), PROBIT in column (2), and IVPROBIT in column (3). In all these specifications, we use the China's IP in Chile as instrument. Columns (4) to (6) follow the same structure in terms of econometric techniques but the impact of the IP index is disaggregated by workers' education levels.

The results in columns (1) to (3) show that the IP had no impact on the overall probability of having an informal job. However, the results by education level reveal an increase in informality among the group of workers with lower levels of education (elementary) - albeit barely significant - when we instrument our PROBIT results using the Chilean IP (column 6). This means that the probability of a typical worker with elementary education of finding an informal job increased by $11.76 \%$ as a result of the increase in the China's IP index between 2001-2010. ${ }^{36}$

Given that Peru experienced remarkable growth throughout the 2000s, in parallel with the

\footnotetext{
${ }^{36}$ To obtain marginal effects, we computed the observed change in the probability of having an informal job by setting the explanatory variables at the sample mean and exploring the changes in this probability that derived from the increase in Chinese import exposure from 2.5 to 10.9, as reported between 2001 and 2010. For the estimation of the marginal effect reported here, the average individual in the sample corresponds to a single male worker who is 35 years old, has graduated from high school, and works in a small firm located in Lima.
} 
Table 6

Estimation results $1^{\text {st }}$ stage - Probability of having a job in the informal sector.

\begin{tabular}{|c|c|c|c|c|c|c|c|c|}
\hline & $\begin{array}{c}(1) \\
\text { Informality }\end{array}$ & $\begin{array}{c}(2) \\
\text { Informality }\end{array}$ & $\begin{array}{c}(3) \\
\text { Informality }\end{array}$ & $\begin{array}{c}(4) \\
\text { Informality }\end{array}$ & $\begin{array}{c}(5) \\
\text { Informality }\end{array}$ & $\begin{array}{c}(6) \\
\text { Informality }\end{array}$ & $\begin{array}{c}(7) \\
\text { Informality }\end{array}$ & $\begin{array}{c}(8) \\
\text { Informality }\end{array}$ \\
\hline \multicolumn{9}{|l|}{ Panel A. Informality - main results } \\
\hline Chinese Import Exposure (\%) - Peru & $\begin{array}{l}-0.00007 \\
(0.00026)\end{array}$ & $\begin{array}{l}-0.00129 \\
(0.00168)\end{array}$ & $\begin{array}{c}0.00756 \\
(0.00714)\end{array}$ & & & & & \\
\hline China I.E. PER * workers with no education & & & & $\begin{array}{l}-0.000438 \\
(0.000417)\end{array}$ & $\begin{array}{c}-0.00399 \\
(0.00892)\end{array}$ & $\begin{array}{l}0.00394 \\
(0.0131)\end{array}$ & $\begin{array}{l}0.00409 \\
(0.0131)\end{array}$ & $\begin{array}{c}0.00278 \\
(0.0130)\end{array}$ \\
\hline China I.E. PER * workers with elementary education & & & & $\begin{array}{c}-0.000171 \\
(0.000317)\end{array}$ & $\begin{array}{c}0.00396 \\
(0.00251)\end{array}$ & $\begin{array}{c}0.0140^{*} \\
(0.00793)\end{array}$ & $\begin{array}{c}0.0144^{*} \\
(0.00768)\end{array}$ & $\begin{array}{c}0.0136^{*} \\
(0.00781)\end{array}$ \\
\hline China I.E. PER * workers with high school education & & & & $\begin{array}{c}-8.05 \mathrm{e}-05 \\
(0.000295)\end{array}$ & $\begin{array}{l}-0.00110 \\
(0.00187)\end{array}$ & $\begin{array}{c}0.00812 \\
(0.00743)\end{array}$ & $\begin{array}{c}0.00860 \\
(0.00700)\end{array}$ & $\begin{array}{c}0.00770 \\
(0.00730)\end{array}$ \\
\hline China I.E. PER * workers with college education & & & & $\begin{array}{c}4.94 \mathrm{e}-05 \\
(0.000348)\end{array}$ & $\begin{array}{l}-0.00231 \\
(0.00192)\end{array}$ & $\begin{array}{c}0.00726 \\
(0.00705)\end{array}$ & $\begin{array}{c}0.00765 \\
(0.00674)\end{array}$ & $\begin{array}{c}0.00689 \\
(0.00691)\end{array}$ \\
\hline Other family member is sub employed & $\begin{array}{c}0.03160^{* * *} \\
(0.00509)\end{array}$ & $\begin{array}{l}0.387^{* * *} \\
(0.0693)\end{array}$ & $\begin{array}{c}0.387^{* * *} \\
(0.0692)\end{array}$ & $\begin{array}{c}0.0316^{* *} \\
(0.00507)\end{array}$ & $\begin{array}{c}0.387^{* * *} \\
(0.0696)\end{array}$ & $\begin{array}{c}0.387^{* * *} \\
(0.0694)\end{array}$ & $\begin{array}{c}0.387^{* * *} \\
(0.0694)\end{array}$ & \\
\hline Industry growth & & & & & & & $\begin{array}{l}-0.237^{*} \\
(0.131)\end{array}$ & \\
\hline Other family member is unemployed & & & & & & & & $\begin{array}{l}0.00299 \\
(0.0579)\end{array}$ \\
\hline \multicolumn{9}{|l|}{ Panel B. $1^{\text {st }}$ stage results - IV Probit } \\
\hline Chinese Import Exposure (\%) - Chile & & & $\begin{array}{c}0.424^{* * *} \\
(0.100)\end{array}$ & & & & & \\
\hline China I.E. CHL * workers with no education & & & & & & $\begin{array}{l}0.839^{* * *} \\
(0.0802)\end{array}$ & $\begin{array}{l}0.838^{* * *} \\
(0.0796)\end{array}$ & $\begin{array}{l}0.839^{* * *} \\
(0.0802)\end{array}$ \\
\hline China I.E. CHL * workers with elementary education & & & & & & $\begin{array}{l}0.896^{* * *} \\
(0.0690)\end{array}$ & $\begin{array}{l}0.896^{* * *} \\
(0.0687)\end{array}$ & $\begin{array}{c}0.896^{* * *} \\
(0.0690)\end{array}$ \\
\hline China I.E. CHL * workers with high school education & & & & & & $\begin{array}{l}0.739^{* * *} \\
(0.0617)\end{array}$ & $\begin{array}{l}0.738^{* * *} \\
(0.0613)\end{array}$ & $\begin{array}{l}0.739^{* * *} \\
(0.0617)\end{array}$ \\
\hline China I.E. CHL * workers with college education & & & & & & $\begin{array}{l}0.972^{* * *} \\
(0.0418)\end{array}$ & $\begin{array}{l}0.972^{* * *} \\
(0.0416)\end{array}$ & $\begin{array}{l}0.972^{* * *} \\
(0.0418)\end{array}$ \\
\hline Observations & 29,919 & 29,919 & 29,919 & 29,919 & 29,919 & 29,919 & 29,919 & 29,919 \\
\hline R-squared & 0.47348 & - & - & 0.474 & - & - & - & - \\
\hline Year FE & Yes & Yes & Yes & Yes & Yes & Yes & Yes & Yes \\
\hline Sector FE & Yes & Yes & Yes & Yes & Yes & Yes & Yes & Yes \\
\hline Instrument & No & No & IP Chile & No & No & IP Chile & IP Chile & IP Chile \\
\hline Method & OLS & PROBIT & IVPROBIT & OLS & PROBIT & IVPROBIT & IVPROBIT & IVPROBIT \\
\hline Exogeneity Test p-value & $\mathrm{N} / \mathrm{A}$ & $\mathrm{N} / \mathrm{A}$ & 0.184 & $\mathrm{~N} / \mathrm{A}$ & $\mathrm{N} / \mathrm{A}$ & 0.661 & 0.636 & 0.691 \\
\hline
\end{tabular}

Notes: Sample weights used in all estimations. Standard errors clustered at the sector-year level. Individual controls included: age, age2, gender, firm-size, education dummy levels. Year, department and sector fixed effects. ${ }^{* *} \mathrm{p}<0.01,{ }^{* *} \mathrm{p}<0.05,{ }^{*} \mathrm{p}<0.1$. 
peak of the China shock, we also control for the growth rate of domestic production in each industry during 2001-2010 - column (7). The coefficient for the group of workers with elementary education remains robust, although still weak. If for example, we consider a worker with the same characteristics described for the results in (6) - that is, someone who is employed in the average industry with annual growth of $8.4 \%$ - the probability of finding an informal job increased $12.1 \%$ as result of Chinese import competition. ${ }^{37}$

Finally, in column (8), we used an alternative exclusion restriction to control for selection bias - we consider whether the household reports that another of its members is unemployed. The result for workers with elementary-level education holds with a similar magnitude and significance level as in (6) and (7). The likelihood of finding a job in the informal sector for a worker with an elementary-level education and the same features, as described before, increased by $11.72 \%$ due to Chinese import competition.

\subsection{Impact on Average Formal and Informal Wages}

Table 7 shows the results from the second stage, using the impact of China's IP on wages. We use two-stage least squares as the econometric technique in all columns. ${ }^{38}$ Columns (1) to (3) show the results for the impact of China's IPs on overall wages, and then on wages in the informal and formal sectors. While we do not find significant evidence on overall wages, we do find evidence that Chinese imports had a positive impact on wages in the formal sector. A 1-percentage-point increase in exposure to China's IP increased formal workers' salaries by $0.9 \%$. This could be reflecting the surge's "complementary effects" in the sense that some of the goods imported from China may have supported the growth of other goods locally produced in industries that largely employ workers in the formal sector. For instance, this could be the case of the imports of construction materials that supported the development of the infrastructure needed to expand the production in some booming local industries/sectors (for instance, metals). This would be consistent with increasing labor demand and wages in those industries/sectors. Additionally, it could also reflect an income effect, given that more imports of final goods at lower prices may have increased the purchasing power of the population and shifted the distribution of expenses in their basket of goods, benefitting some sectors (with workers who may be employed formally) more than others. ${ }^{39}$

\footnotetext{
${ }^{37}$ The average annual industry growth corresponds to the sample mean for the industry development variable in the period analyzed.

${ }^{38}$ We correct the standard errors using 1010-repetition bootstrap to estimate informal and formal wages, equations (4) and (5). Because we do not have selection bias on the estimation for overall wages (formal and informal), we do not need to incorporate the inverse of mills.

${ }^{39}$ To further explore potential differences in the impact by industry, we also estimated the impact by the degree of exposure to the surge. In a robustness exercise, we calculated the average China's IP during 1996-1999 (previous to the 2000s) and classified the industries as "more" (the upper half of the industry distribution) and "less" (the lower half of industries by exposure) exposed to Chinese imports based on that period's categorization. Then, we calculated the IP's impact in the 2000s, by exposure group (more and less exposed). We found that even though some industries had a higher IP before the 2000s, there was no significant impact on informality and wages for either group. In other words, being more exposed to the surge did not make any difference, at least statistically. We left these results out of the paper for simplicity purposes, however, they are available upon request.
} 
Table 7

Estimation results on monthly real Wages - $2^{\text {nd }}$ stage.

\begin{tabular}{|c|c|c|c|c|c|c|c|c|c|}
\hline & $\begin{array}{c}(1) \\
\text { Wages } \\
\text { All } \\
\end{array}$ & $\begin{array}{c}(2) \\
\text { Wages } \\
\text { Informal }\end{array}$ & $\begin{array}{c}(3) \\
\text { Wages } \\
\text { Formal }\end{array}$ & $\begin{array}{c}(4) \\
\text { Wages } \\
\text { All } \\
\end{array}$ & $\begin{array}{c}(5) \\
\text { Wages } \\
\text { Informal }\end{array}$ & $\begin{array}{c}(6) \\
\text { Wages } \\
\text { Formal }\end{array}$ & $\begin{array}{c}(7) \\
\text { Wages } \\
\text { All }\end{array}$ & $\begin{array}{c}(8) \\
\text { Wages } \\
\text { Informal }\end{array}$ & $\begin{array}{c}(9) \\
\text { Wages } \\
\text { Formal }\end{array}$ \\
\hline \multicolumn{10}{|l|}{ Panel A. Wages $-2^{\text {nd }}$ stage results } \\
\hline Chinese Import Exposure (\%) - Peru & $\begin{array}{l}-0.00512 \\
(0.00466)\end{array}$ & $\begin{array}{l}-0.00902 \\
(0.00666)\end{array}$ & $\begin{array}{c}0.00912^{* *} \\
(0.00431)\end{array}$ & & & & & & \\
\hline $\begin{array}{l}\text { China I.E. PER * workers with } \\
\text { no education }\end{array}$ & & & & $\begin{array}{l}-0.0162^{* *} \\
(0.00684)\end{array}$ & $\begin{array}{c}-0.0191^{* * *} \\
(0.00676)\end{array}$ & $\begin{array}{l}0.00497 \\
(0.0115)\end{array}$ & $\begin{array}{l}-0.0162^{* *} \\
(0.00684)\end{array}$ & $\begin{array}{c}-0.0192^{* * *} \\
(0.00679)\end{array}$ & $\begin{array}{l}0.00495 \\
(0.0116)\end{array}$ \\
\hline $\begin{array}{l}\text { China I.E. PER * workers with } \\
\text { elementary education }\end{array}$ & & & & $\begin{array}{l}-0.0109^{*} \\
(0.00553)\end{array}$ & $\begin{array}{l}-0.0140^{* *} \\
(0.00605)\end{array}$ & $\begin{array}{l}0.0126^{* * *} \\
(0.00478)\end{array}$ & $\begin{array}{l}-0.0109^{*} \\
(0.00553)\end{array}$ & $\begin{array}{l}-0.0142^{* *} \\
(0.00605)\end{array}$ & $\begin{array}{l}0.0128^{* *} \\
(0.00508)\end{array}$ \\
\hline China I.E. PER * workers with & & & & -0.00251 & -0.00667 & $0.0107^{* *}$ & -0.00251 & -0.00681 & $0.0109^{* *}$ \\
\hline high school education & & & & $(0.00415)$ & $(0.00533)$ & $(0.00441)$ & $(0.00415)$ & $(0.00533)$ & $(0.00458)$ \\
\hline China I.E. PER * workers with & & & & -0.00448 & -0.00717 & $0.00742^{*}$ & -0.00448 & -0.00739 & $0.00752^{*}$ \\
\hline college education & & & & $(0.00390)$ & $(0.00541)$ & $(0.00439)$ & $(0.00390)$ & $(0.00540)$ & $(0.00454)$ \\
\hline Inverse mills ratio (sub-employed) & & $\begin{array}{c}-0.205^{* * *} \\
(0.0720)\end{array}$ & $\begin{array}{l}1.058 \\
(0.131)\end{array}$ & & $\begin{array}{l}-0.182^{* *} \\
(0.0723)\end{array}$ & $\begin{array}{c}1.038^{* * *} \\
(0.134)\end{array}$ & & & \\
\hline Inverse mills ratio (unemployed) & & & & & & & & $\begin{array}{c}-0.341^{* * *} \\
(0.0721)\end{array}$ & $\begin{array}{c}1.063^{* * *} \\
(0.187)\end{array}$ \\
\hline \multicolumn{10}{|l|}{ Panel B. $1^{\text {st }}$ stage results - IV Probit } \\
\hline Chinese Import Exposure (\%) - Chile & $\begin{array}{l}0.42501^{* * *} \\
(0.1007)\end{array}$ & $\begin{array}{c}0.41772^{* * *} \\
(0.12751)\end{array}$ & $\begin{array}{c}0.38822^{* *} \\
(0.15395)\end{array}$ & & & & & & \\
\hline $\begin{array}{l}\text { China I.E. CHL * workers with } \\
\text { no education }\end{array}$ & & & & $\begin{array}{l}0.82304^{* * *} \\
(0.0798)\end{array}$ & $\begin{array}{l}-0.21972^{* * *} \\
(0.07903)\end{array}$ & $\begin{array}{c}0.068641^{* *} \\
(0.33022)\end{array}$ & $\begin{array}{l}0.82304^{* * *} \\
(0.0798)\end{array}$ & $\begin{array}{c}-0.22297^{* * *} \\
(0.07903)\end{array}$ & $\begin{array}{l}0.053773^{* *} \\
(0.3302)\end{array}$ \\
\hline $\begin{array}{l}\text { China I.E. CHL * workers with } \\
\text { elementary education }\end{array}$ & & & & $\begin{array}{l}0.88844^{* * *} \\
(0.070)\end{array}$ & $\begin{array}{c}-0.36426^{* * *} \\
(0.07448)\end{array}$ & $\begin{array}{c}0.27013^{* * *} \\
(0.08218)\end{array}$ & $\begin{array}{l}0.88844^{* * *} \\
(0.072)\end{array}$ & $\begin{array}{c}-0.36493^{* * *} \\
(0.07449)\end{array}$ & $\begin{array}{l}0.4769^{* * *} \\
(0.08204)\end{array}$ \\
\hline China I.E. CHL * workers with & & & & $0.74213^{* * *}$ & $-0.23985^{* * *}$ & $-0.30506^{* * *}$ & $0.74213^{* * *}$ & $-0.23709^{* * *}$ & $-0.018508^{* * *}$ \\
\hline high school education & & & & $(0.062)$ & $(0.06657)$ & $(0.09135)$ & $(0.062)$ & $(0.06661)$ & $(0.08984)$ \\
\hline $\begin{array}{l}\text { China I.E. CHL * workers with } \\
\text { college education }\end{array}$ & & & & $\begin{array}{l}0.97068^{* * *} \\
\quad(0.042)\end{array}$ & $\begin{array}{l}-0.068825^{* * *} \\
(0.04466)\end{array}$ & $\begin{array}{c}-1.00248^{* * *} \\
(0.06692)\end{array}$ & $\begin{array}{l}0.97068^{* * *} \\
\quad(0.042)\end{array}$ & $\begin{array}{c}-0.067619^{* * *} \\
(0.04466)\end{array}$ & $\begin{array}{c}-1.14885^{* * *} \\
(0.06769)\end{array}$ \\
\hline Observations & 27,930 & 23,222 & 4,708 & 27,930 & 23,222 & 4,708 & 27,930 & 23,222 & 4,708 \\
\hline R-squared & 0.441 & 0.356 & 0.318 & 0.442 & 0.356 & 0.319 & 0.442 & 0.357 & 0.314 \\
\hline Instrument & IP Chile & IP Chile & IP Chile & IP Chile & IP Chile & IP Chile & IP Chile & IP Chile & IP Chile \\
\hline Method & 2SLS & 2SLS & $2 \mathrm{SLS}$ & 2SLS & 2SLS & 2SLS & 2SLS & 2SLS & 2SLS \\
\hline Underidentification p-value & 0.00122 & 0.00125 & 0.000458 & 0.00121 & 0.00122 & 0.000422 & 0.00121 & 0.00122 & 0.000219 \\
\hline
\end{tabular}

Notes: Sample weights used in all estimations. Standard errors clustered at the sector-year level for estimations on Wages All (columns 1, 4 and 7). Standard errors are bootstrapped for estimations on Wages Informal (columns 2, 5 and 8) and Wages Formal (columns 3,6 and 9). Individual controls included: age, age2, gender, firm-size, education dummy levels. Year, department and sector fixed effects. ${ }^{* *} \mathrm{p}<0.01,{ }^{* *} \mathrm{p}<0.05,{ }^{*} \mathrm{p}<0.1$. 
To further assess these effects, we decompose the impact by workers' education levels. First, in column (4), we obtain a negative impact on overall wages for the least educated workers - those with either no education or elementary-level education. The results suggest that a 1 percentagepoint increase in the Chinese IP lowered overall salaries by approximately $1.6 \%$ and $1.1 \%$ for workers with no education and elementary-level education, respectively. Second, we find that the results on overall wages are consistent with the patterns in the informal sector. The results for wages in the informal sector in column (5) are qualitatively similar and stronger than those in (4). A 1-percentage-point increase in exposure to China's IP decreased informal workers' wages by $1.9 \%$ and $1.4 \%$ for workers with no education and elementary-level education, respectively. These results can be explained by the "substitution effects" from the surge. In particular, the surge of imports from China also introduced lower-cost final goods that competed with similar goods locally produced, lowering the demand for the latter and bringing the wages of workers in those industries down in the process. Digging into the industries behind these results, we find that largest decreases in wages among workers with elementary education in the informal sector were in leather and footwear, textiles, and apparel. Wages for workers with elementary education in these industries went down by $75 \%, 38 \%$ and 33\%, respectively between 2001 and 2010 .

Finally, as we saw above, not all effects are negative. We find that the previous favorable wage dynamics in (3) holds for most educational groups in the formal sector - except for workers with no education who are rare in the formal sector. The impact can be interpreted as a 1percentage-point increase in the exposure to Chinese import exposure increased formal workers' wages by $1.3 \%, 1.1 \%$ and $0.7 \%$ for individuals with elementary, high school and college education, respectively. Looking into the potential group of workers in the formal sector behind these results, we find that the largest increase in wages between 2001-2010 was for individuals working in the manufacture of basic metals (or metal-related industries), followed by non-metallic mineral products and food. Considering that the metal industry has a heavy concentration of workers in the formal sector, it is possible that the positive effects we find are partly explained by developments in this industry, which grew considerably during the period studied, and may have benefitted from the surge of imports of complementary goods (such as material for construction) from China.

The mixed evidence reveals important repercussion in the Peruvian labor market. On one side, when focusing on the detrimental impact in the informal sector-which represented $79 \%$ of the total employment in 2010 - we calculate a decrease of approximately $16 \%$ and $12 \%$ on real wages - considering that the Chinese IP index increased 8.4 percentage points in 2001-2010for workers with no education and elementary-level education, respectively. On the other side, having the same considerations for the increase in the Chinese IP index, the positive impact in the formal sector - which is a smaller share of the labor force, only $19 \%$ in 2010 - can be estimated as an increase of $10.6 \%, 9 \%$, and $6.2 \%$ on real wages for workers with elementary, high school and college education, respectively.

In columns (7) to (9), we use the inverse Mills ratios with an alternative exclusion restrictionanother household member who is unemployed - and the results were almost identical. 
Table 8

Estimation results - $2^{\text {nd }}$ stage, including industry development.

\begin{tabular}{|c|c|c|c|c|c|c|}
\hline & $\begin{array}{c}(1) \\
\text { Wages All }\end{array}$ & $\begin{array}{c}(2) \\
\text { Wages Informal }\end{array}$ & $\begin{array}{c}(3) \\
\text { Wages Formal }\end{array}$ & $\begin{array}{c}(4) \\
\text { Wages All }\end{array}$ & $\begin{array}{c}(5) \\
\text { Wages Informal }\end{array}$ & $\begin{array}{c}(6) \\
\text { Wages Formal }\end{array}$ \\
\hline \multicolumn{7}{|l|}{ Panel A. Wages $-2^{\text {nd }}$ stage results } \\
\hline China I.E. PER * workers with no education & $\begin{array}{l}-0.0164^{* *} \\
(0.00640)\end{array}$ & $\begin{array}{c}-0.0194^{* * *} \\
(0.00648)\end{array}$ & $\begin{array}{l}0.00507 \\
(0.0116)\end{array}$ & $\begin{array}{c}-0.0164^{* *} \\
(0.00640)\end{array}$ & $\begin{array}{c}-0.0195^{* * *} \\
(0.00651)\end{array}$ & $\begin{array}{l}0.00507 \\
(0.0118)\end{array}$ \\
\hline China I.E. PER * workers with elementary education & $\begin{array}{l}-0.0111^{* *} \\
(0.00537)\end{array}$ & $\begin{array}{l}-0.0143^{* *} \\
(0.00591)\end{array}$ & $\begin{array}{l}0.0129^{* *} \\
(0.00524)\end{array}$ & $\begin{array}{l}-0.0111^{* *} \\
(0.00537)\end{array}$ & $\begin{array}{l}-0.0145^{* *} \\
(0.00592)\end{array}$ & $\begin{array}{l}0.0131^{* *} \\
(0.00555)\end{array}$ \\
\hline China I.E. PER * workers with high school education & $\begin{array}{l}-0.00277 \\
(0.00403)\end{array}$ & $\begin{array}{l}-0.00704 \\
(0.00524)\end{array}$ & $\begin{array}{l}0.0112^{* *} \\
(0.00484)\end{array}$ & $\begin{array}{l}-0.00277 \\
(0.00403)\end{array}$ & $\begin{array}{l}-0.00719 \\
(0.00524)\end{array}$ & $\begin{array}{l}0.0114^{* *} \\
(0.00503)\end{array}$ \\
\hline China I.E. PER * workers with college education & $\begin{array}{l}-0.00471 \\
(0.00390)\end{array}$ & $\begin{array}{l}-0.00751 \\
(0.00531)\end{array}$ & $\begin{array}{c}0.00778 \\
(0.00481)\end{array}$ & $\begin{array}{l}-0.00471 \\
(0.00390)\end{array}$ & $\begin{array}{l}-0.00773 \\
(0.00531)\end{array}$ & $\begin{array}{c}0.00790 \\
(0.00498)\end{array}$ \\
\hline Inverse mills ratio (sub-employed) & & $\begin{array}{c}-0.187^{* * *} \\
(0.0724)\end{array}$ & $\begin{array}{c}1.040^{* * *} \\
(0.145)\end{array}$ & & & \\
\hline Industry development & $\begin{array}{l}0.144^{*} \\
(0.0747)\end{array}$ & $\begin{array}{c}0.198^{* *} \\
(0.101)\end{array}$ & $\begin{array}{c}-0.244^{* *} \\
(0.100)\end{array}$ & $\begin{array}{c}0.144^{*} \\
(0.0747)\end{array}$ & $\begin{array}{l}0.201^{* *} \\
(0.101)\end{array}$ & $\begin{array}{c}-0.242^{\star *} \\
(0.101)\end{array}$ \\
\hline Inverse mills ratio (unemployed) & & & & & $\begin{array}{c}-0.346^{* * *} \\
(0.0722)\end{array}$ & $\begin{array}{c}1.066^{* * *} \\
(0.202)\end{array}$ \\
\hline \multicolumn{7}{|l|}{ Panel B. $1^{\text {st }}$ stage results - IV Probit } \\
\hline China I.E. CHL * workers with no education & $\begin{array}{c}0.82290^{* * *} \\
(0.079)\end{array}$ & $\begin{array}{c}-0.21419^{* * *} \\
(0.07845)\end{array}$ & $\begin{array}{c}0.071609^{* *} \\
(0.33009)\end{array}$ & $\begin{array}{c}0.82290^{* * *} \\
(0.079)\end{array}$ & $\begin{array}{c}-0.21738^{* * *} \\
(0.07841)\end{array}$ & $\begin{array}{c}0.056941^{* *} \\
(0.33007)\end{array}$ \\
\hline China I.E. CHL * workers with elementary education & $\begin{array}{c}0.88799^{* * *} \\
(0.070)\end{array}$ & $\begin{array}{c}-0.36942^{* * *} \\
(0.07389)\end{array}$ & $\begin{array}{c}0.27668^{* * *} \\
(0.08224)\end{array}$ & $\begin{array}{c}0.88799^{* * *} \\
(0.070)\end{array}$ & $\begin{array}{c}-0.37001^{* * *} \\
(0.07386)\end{array}$ & $\begin{array}{c}0.47615^{* * *} \\
(0.08211)\end{array}$ \\
\hline China I.E. CHL * workers with high school education & $\begin{array}{c}0.74118^{* * *} \\
(0.061)\end{array}$ & $\begin{array}{c}-0.2369^{* * *} \\
(0.06669)\end{array}$ & $\begin{array}{c}-0.3987^{* * *} \\
(0.08998)\end{array}$ & $\begin{array}{c}0.74118^{* * *} \\
\quad(0.061)\end{array}$ & $\begin{array}{c}-0.23363^{* * *} \\
(0.06671)\end{array}$ & $\begin{array}{c}-0.11565^{* * *} \\
(0.08842)\end{array}$ \\
\hline China I.E. CHL * workers with college education & $\begin{array}{c}0.97030^{* * *} \\
(0.042)\end{array}$ & $\begin{array}{c}-0.068381^{* * *} \\
(0.04515)\end{array}$ & $\begin{array}{c}-1.05107^{* * *} \\
(0.06706)\end{array}$ & $\begin{array}{l}0.97030^{* * *} \\
\quad(0.042)\end{array}$ & $\begin{array}{c}-0.067171^{* * *} \\
(0.04513)\end{array}$ & $\begin{array}{c}-1.19583^{* * *} \\
(0.06777)\end{array}$ \\
\hline Observations & 27,930 & 23,222 & 4,708 & 27,930 & 23,222 & 4,708 \\
\hline R-squared & 0.442 & 0.357 & 0.318 & 0.442 & 0.357 & 0.314 \\
\hline Instrument & IP Chile & IP Chile & IP Chile & IP Chile & IP Chile & IP Chile \\
\hline Method & 2SLS & 2SLS & 2SLS & 2SLS & 2SLS & 2SLS \\
\hline Underidentification p-value & 0.00109 & 0.00108 & 0.000340 & 0.00109 & 0.00108 & 0.000170 \\
\hline
\end{tabular}

Notes: Sample weights used in all estimations. Standard errors clustered at the sector-year level for estimations on Wages All (columns 1 and 4 ).

Standard errors are bootstrapped for estimations on Wages Informal (columns 2 and 5) and Wages Formal (columns 3 and 6). Individual controls

included: age, age2, gender, firm-size, education dummy levels. Year, department and sector fixed effects. ${ }^{* *} \mathrm{p}<0.01,{ }^{* *} \mathrm{p}<0.05,{ }^{*} \mathrm{p}<0.1$. 
Two technical aspects to note in this estimation. First, the coefficients for the Mills ratios built from the first-stage regression are significant in almost all the specifications, which suggests that controlling for self-selection into informal jobs is adequate for the study of the effects of the China shock on wages. Second, results including the Chilean IP as instrument prove to be robust and have strong statistical power, thus, Chile's exposure to Chinese imports is an appropriate instrument. ${ }^{40}$

Given the expansion of the manufacturing sector over this period, the results in Table 8 repeat the estimation in columns (4) to (9) from Table 7 but controlling for industry growth - domestic production annual growth at the industry level. In columns (1) to (3), the inverse Mills ratios are built using the variable that considers whether another household member is sub employed, while columns (4) to (6) do the same using the variable that considers whether another household member is unemployed. The results for overall wages and both informal and formal wages remain robust and are similar - even in magnitude - to those in Table 7, except for the group of workers with college education. The effects on these workers' wages disappears.

\subsection{The Role of Self-Employed Workers}

As we analyze informality, one important element to consider is the presence of self-employed workers in the sample. Self-employed could be workers engaged in casual work oftentimes in informal conditions. In this case, self-employed workers are not a trivial component - they explain a third of the overall sample and $44 \%$ of the informal-worker sample. They are overwhelmingly placed in informal jobs - $99 \%$ of them-and near half of them-45\% has either no education or elementary education. Thus, given their importance, especially within the group of informal workers, we reproduce the estimations in Tables 6 and 7 excluding them from the sample, and we assess the robustness of the results.

The results are presented in Tables 9a, 9b and 9c. The results for the overall sample and for the segment unaffected by the exclusion of self-employed workers - formal jobs-hold. First, in terms of the probability of having an informal job, estimates excluding self-employed workers in Table 9a suggest that the results are consistent: IP had no impact on the overall probability for having an informal job, and the relative increase in the probability of finding an informal job among workers with elementary education remains significant although the coefficient has a slightly lower magnitude.

The positive impact of China's IP on wages for the formal sector holds in similar magnitude for workers with elementary and high school education, even when we account for the industry growth (Column 6 in Tables 9b and 9c). The positive result for workers with college education

\footnotetext{
${ }^{40}$ All the $F$-statistics of the endogenous' first stage are very powerful and statistically significant, thus, proving to have a strong relation with the Peruvian IP variable. Furthermore, results from the weak instrument test on columns (2) and (3) - with only 1 endogenous variable - discard potential bias coming from our instrument. Finally, we also looked at Stock and Yogo (2005) to determine if the weak instrument tests were rejected when we included 4 endogenous variables, and we could not reject. Moreover, according to the tables of Stock and Yogo (2005), there is no estimation (yet calculated) of the bias size in models with more than 3 endogenous variables (as it is in our paper). Thus, the $F$-statistics are not comparable with any available criteria to determine instruments' weakness.
} 
Table 9

Estimation results excluding self-employed workers.

(a) Probability of having an informal job.

\begin{tabular}{|c|c|c|c|c|c|c|c|c|}
\hline & $\begin{array}{c}(1) \\
\text { Informality }\end{array}$ & $\begin{array}{c}(2) \\
\text { Informality }\end{array}$ & $\begin{array}{c}(3) \\
\text { Informality }\end{array}$ & $\begin{array}{c}(4) \\
\text { Informality }\end{array}$ & $\begin{array}{c}(5) \\
\text { Informality }\end{array}$ & $\begin{array}{c}(6) \\
\text { Informality }\end{array}$ & $\begin{array}{c}(7) \\
\text { Informality }\end{array}$ & $\begin{array}{c}(8) \\
\text { Informality }\end{array}$ \\
\hline Panel A. Informality - main results & & & & & & & & \\
\hline Chinese Import Exposure (\%) - Peru & $\begin{array}{l}-0.00015 \\
(0.00036)\end{array}$ & $\begin{array}{c}-0.000996 \\
(0.00172)\end{array}$ & $\begin{array}{c}0.00720 \\
(0.00666)\end{array}$ & & & & & \\
\hline China I.E. PER * workers with no education & & & & $\begin{array}{c}-0.00107 \\
(0.000826)\end{array}$ & $\begin{array}{l}-0.00552 \\
(0.00991)\end{array}$ & $\begin{array}{l}0.00107 \\
(0.0122)\end{array}$ & $\begin{array}{l}0.00126 \\
(0.0123)\end{array}$ & $\begin{array}{c}0.000189 \\
(0.0122)\end{array}$ \\
\hline China I.E. PER * workers with elementary education & & & & $\begin{array}{c}0.000232 \\
(0.000454)\end{array}$ & $\begin{array}{c}0.00413 \\
(0.00259)\end{array}$ & $\begin{array}{c}0.0131^{*} \\
(0.00711)\end{array}$ & $\begin{array}{c}0.0134^{*} \\
(0.00692)\end{array}$ & $\begin{array}{c}0.0128^{*} \\
(0.00703)\end{array}$ \\
\hline China I.E. PER * workers with high school education & & & & $\begin{array}{l}-0.000179 \\
(0.000400)\end{array}$ & $\begin{array}{l}-0.000798 \\
(0.00190)\end{array}$ & $\begin{array}{c}0.00773 \\
(0.00695)\end{array}$ & $\begin{array}{c}0.00821 \\
(0.00659)\end{array}$ & $\begin{array}{c}0.00749 \\
(0.00685)\end{array}$ \\
\hline China I.E. PER * workers with college education & & & & $\begin{array}{l}-0.000148 \\
(0.000441)\end{array}$ & $\begin{array}{l}-0.00194 \\
(0.00198)\end{array}$ & $\begin{array}{c}0.00689 \\
(0.00659)\end{array}$ & $\begin{array}{c}0.00729 \\
(0.00635)\end{array}$ & $\begin{array}{c}0.00670 \\
(0.00649)\end{array}$ \\
\hline Other family member is sub employed & $\begin{array}{c}0.04995^{* * *} \\
(0.00920)\end{array}$ & $\begin{array}{c}0.369^{* * *} * \\
(0.0721)\end{array}$ & $\begin{array}{c}0.368^{* * *} * \\
(0.0720)\end{array}$ & $\begin{array}{c}0.0500 * * * \\
(0.00919)\end{array}$ & $\begin{array}{c}0.369^{* * *} \\
(0.0723)\end{array}$ & $\begin{array}{c}0.368^{* * *} \\
(0.0721)\end{array}$ & $\begin{array}{c}0.368^{* * *} \\
(0.0722)\end{array}$ & \\
\hline Industry growth & & & & & & & $\begin{array}{c}-0.214^{*} \\
(0.126)\end{array}$ & \\
\hline Other family member is unemployed & & & & & & & & $\begin{array}{l}0.00322 \\
(0.0584)\end{array}$ \\
\hline $\begin{array}{l}\text { Panel B. } \mathbf{1}^{\text {st }} \text { stage results - IV Probit } \\
\text { Chinese Import Exposure (\%) - Chile }\end{array}$ & & & $\begin{array}{c}0.465^{* * *} \\
(0.116)\end{array}$ & & & & & \\
\hline China I.E. CHL * workers with no education & & & & & & $\begin{array}{l}1.011^{* * *} \\
(0.0734)\end{array}$ & $\begin{array}{l}1.010^{* * *} \\
(0.0734)\end{array}$ & $\begin{array}{l}1.011^{* * *} \\
(0.0734)\end{array}$ \\
\hline China I.E. CHL * workers with elementary education & & & & & & $\begin{array}{c}1.072^{* * *} \\
(0.0489)\end{array}$ & $\begin{array}{c}1.072^{* * *} \\
(0.0489)\end{array}$ & $\begin{array}{c}1.072^{* * *} \\
(0.0489)\end{array}$ \\
\hline China I.E. CHL * workers with high school education & & & & & & $\begin{array}{c}0.715^{* * *} \\
(0.0720)\end{array}$ & $\begin{array}{l}0.713^{* * *} \\
(0.0717)\end{array}$ & $\begin{array}{c}0.715^{* * *} \\
(0.0721)\end{array}$ \\
\hline China I.E. CHL * workers with college education & & & & & & $\begin{array}{c}0.967^{* * *} \\
(0.0408)\end{array}$ & $\begin{array}{r}0.966^{* * *} \\
(0.0405)\end{array}$ & $\begin{array}{r}0.967^{* * *} \\
(0.0409)\end{array}$ \\
\hline Observations & 19,834 & 19,834 & 19,834 & 19,834 & 19,834 & 19,834 & 19,834 & 19,834 \\
\hline R-squared & 0.42937 & - & - & 0.429 & - & - & - & - \\
\hline Year FE & Yes & Yes & Yes & Yes & Yes & Yes & Yes & Yes \\
\hline Sector FE & Yes & Yes & Yes & Yes & Yes & Yes & Yes & Yes \\
\hline Instrument & No & No & IP Chile & No & No & IP Chile & IP Chile & IP Chile \\
\hline Method & OLS & PROBIT & IVPROBIT & OLS & PROBIT & IVPROBIT & IVPROBIT & IVPROBIT \\
\hline Exogeneity Test p-value & $\mathrm{N} / \mathrm{A}$ & $\mathrm{N} / \mathrm{A}$ & 0.184 & $\mathrm{~N} / \mathrm{A}$ & $\mathrm{N} / \mathrm{A}$ & 0.630 & 0.605 & 0.660 \\
\hline
\end{tabular}

Notes: Sample weights used in all estimations. Standard errors clustered at the sector-year level. Individual controls included: age, age2, gender, firm-size, education dummy levels. Year, department and sector fixed effects. ${ }^{* *} \mathrm{p}<0.01,{ }^{* *} \mathrm{p}<0.05,{ }^{*} \mathrm{p}<0.1$. 
(b) Estimation results on monthly real Wages - $2^{\text {nd }}$ stage.

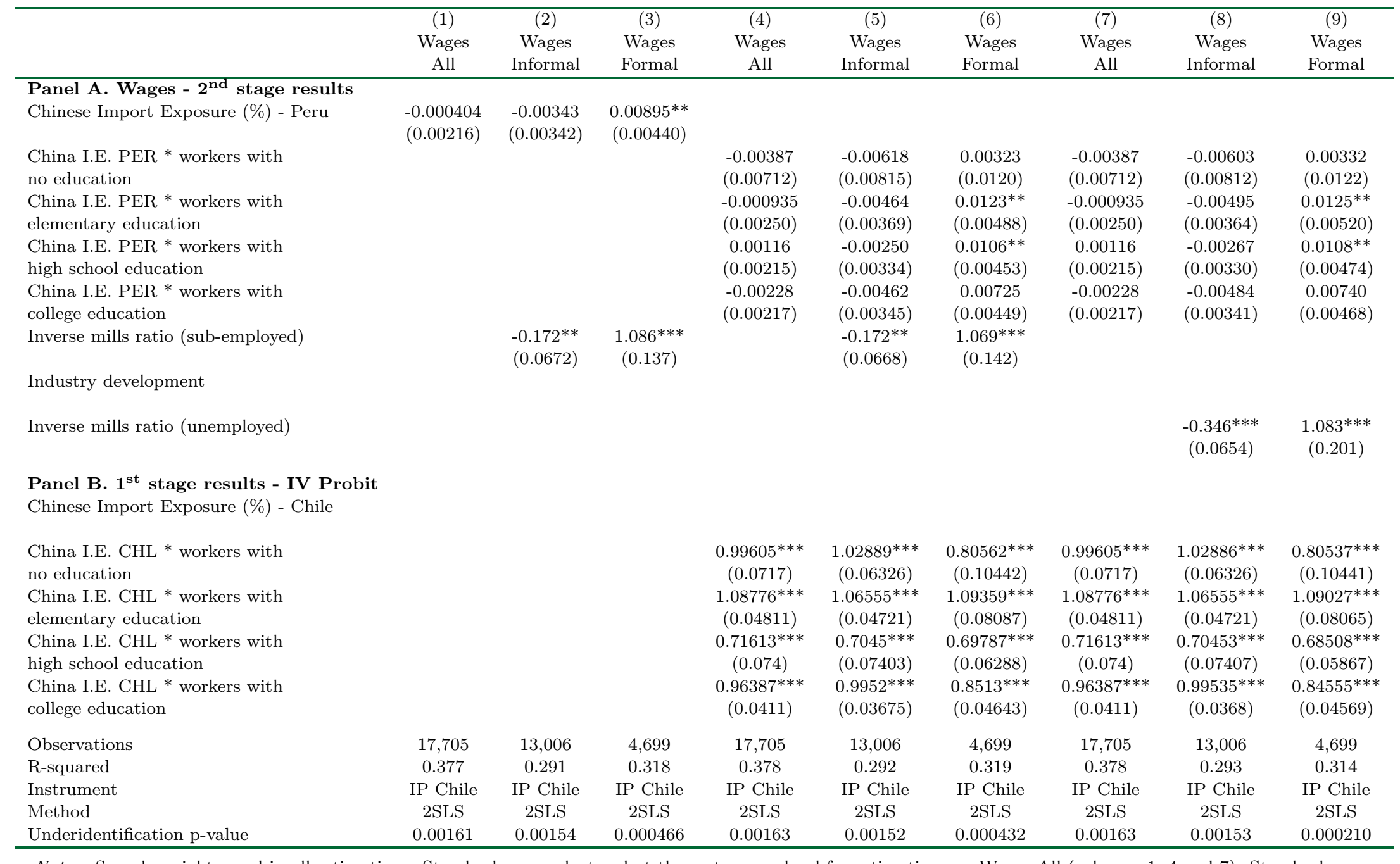

Notes: Sample weights used in all estimations. Standard errors clustered at the sector-year level for estimations on Wages All (columns 1, 4 and 7 ). Standard errors are bootstrapped for estimations on Wages Informal (columns 2, 5 and 8) and Wages Formal (columns 3, 6 and 9). Individual controls included: age, age2, gender, firm-size, education dummy levels. Year, department and sector fixed effects. ${ }^{* *} \mathrm{p}<0.01,{ }^{* *} \mathrm{p}<0.05,{ }^{*} \mathrm{p}<0.1$. 
(c) Estimation Results - $2^{\text {nd }}$ stage, including industry development.

\begin{tabular}{|c|c|c|c|c|c|c|}
\hline & $\begin{array}{c}(1) \\
\text { Wages All }\end{array}$ & $\begin{array}{c}(2) \\
\text { Wages Informal }\end{array}$ & $\begin{array}{c}(3) \\
\text { Wages Formal }\end{array}$ & $\begin{array}{c}(4) \\
\text { Wages All }\end{array}$ & $\begin{array}{c}(5) \\
\text { Wages Informal }\end{array}$ & $\begin{array}{c}(6) \\
\text { Wages Formal }\end{array}$ \\
\hline \multicolumn{7}{|l|}{ Panel A. Wages - $2^{\text {nd }}$ stage results } \\
\hline China I.E. PER * workers with no education & $\begin{array}{l}-0.00398 \\
(0.00707)\end{array}$ & $\begin{array}{l}-0.00649 \\
(0.00809)\end{array}$ & $\begin{array}{l}0.00336 \\
(0.0122)\end{array}$ & $\begin{array}{l}-0.00398 \\
(0.00707)\end{array}$ & $\begin{array}{l}-0.00636 \\
(0.00808)\end{array}$ & $\begin{array}{l}0.00346 \\
(0.0124)\end{array}$ \\
\hline China I.E. PER * workers with elementary education & $\begin{array}{l}-0.00102 \\
(0.00253)\end{array}$ & $\begin{array}{l}-0.00488 \\
(0.00383)\end{array}$ & $\begin{array}{l}0.0126^{* *} \\
(0.00529)\end{array}$ & $\begin{array}{l}-0.00102 \\
(0.00253)\end{array}$ & $\begin{array}{l}-0.00520 \\
(0.00379)\end{array}$ & $\begin{array}{l}0.0128^{* *} \\
(0.00565)\end{array}$ \\
\hline China I.E. PER * workers with high school education & $\begin{array}{c}0.00107 \\
(0.00222)\end{array}$ & $\begin{array}{l}-0.00274 \\
(0.00351)\end{array}$ & $\begin{array}{l}0.0111^{* *} \\
(0.00493)\end{array}$ & $\begin{array}{c}0.00107 \\
(0.00222)\end{array}$ & $\begin{array}{l}-0.00292 \\
(0.00347)\end{array}$ & $\begin{array}{l}0.0113^{* *} \\
(0.00518)\end{array}$ \\
\hline China I.E. PER * workers with college education & $\begin{array}{l}-0.00236 \\
(0.00222)\end{array}$ & $\begin{array}{l}-0.00485 \\
(0.00359)\end{array}$ & $\begin{array}{c}0.00762 \\
(0.00488)\end{array}$ & $\begin{array}{l}-0.00236 \\
(0.00222)\end{array}$ & $\begin{array}{l}-0.00507 \\
(0.00355)\end{array}$ & $\begin{array}{c}0.00778 \\
(0.00511)\end{array}$ \\
\hline Inverse mills ratio (sub-employed) & & $\begin{array}{c}-0.174^{* * *} \\
(0.0667)\end{array}$ & $\begin{array}{c}1.071^{* * *} \\
(0.153)\end{array}$ & & & \\
\hline Industry development & $\begin{array}{c}0.0261 \\
(0.0469)\end{array}$ & $\begin{array}{c}0.0625 \\
(0.0830)\end{array}$ & $\begin{array}{l}-0.229^{* *} \\
(0.0968)\end{array}$ & $\begin{array}{c}0.0261 \\
(0.0469)\end{array}$ & $\begin{array}{c}0.0654 \\
(0.0823)\end{array}$ & $\begin{array}{l}-0.226^{* *} \\
(0.0965)\end{array}$ \\
\hline Inverse mills ratio (unemployed) & & & & & $\begin{array}{c}-0.347^{* * *} \\
(0.0653)\end{array}$ & $\begin{array}{c}1.085^{* * *} \\
(0.216)\end{array}$ \\
\hline \multicolumn{7}{|l|}{ Panel B. $1^{\text {st }}$ stage results - IV Probit } \\
\hline China I.E. CHL * workers with no education & $\begin{array}{c}0.99586^{* * *} \\
(0.07166)\end{array}$ & $\begin{array}{c}1.02859^{* * *} \\
(0.06329)\end{array}$ & $\begin{array}{c}0.80558^{* * *} \\
(0.10441)\end{array}$ & $\begin{array}{c}0.99586^{* * *} \\
(0.07166)\end{array}$ & $\begin{array}{c}1.02855^{* * *} \\
(0.06329)\end{array}$ & $\begin{array}{c}0.80535^{* * *} \\
(0.1044)\end{array}$ \\
\hline China I.E. CHL * workers with elementary education & $\begin{array}{c}1.08776^{* * *} \\
(0.04814)\end{array}$ & $\begin{array}{c}1.06539^{* * *} \\
(0.04724)\end{array}$ & $\begin{array}{c}1.09339^{* * *} \\
(0.08096)\end{array}$ & $\begin{array}{c}1.08776^{* * *} \\
(0.04814)\end{array}$ & $\begin{array}{c}1.06539 * * * \\
(0.04723)\end{array}$ & $\begin{array}{c}1.0901^{* * *} \\
(0.08076)\end{array}$ \\
\hline China I.E. CHL * workers with high school education & $\begin{array}{c}0.71416^{* * *} \\
(0.07367)\end{array}$ & $\begin{array}{c}0.70245^{* * * *} \\
(0.07389)\end{array}$ & $\begin{array}{c}0.6931^{* * *} \\
(0.06137)\end{array}$ & $\begin{array}{c}0.71416^{* * *} \\
(0.07367)\end{array}$ & $\begin{array}{c}0.70248^{* * *} \\
(0.07392)\end{array}$ & $\begin{array}{c}0.67889 * * * \\
(0.05722)\end{array}$ \\
\hline China I.E. CHL * workers with college education & $\begin{array}{c}0.96288^{* * *} \\
(0.041)\end{array}$ & $\begin{array}{l}0.99441^{* * *} \\
\quad(0.037)\end{array}$ & $\begin{array}{c}0.85006^{* * * *} \\
\quad(0.046)\end{array}$ & $\begin{array}{c}0.96288^{* * *} \\
\quad(0.041)\end{array}$ & $\begin{array}{c}0.99455^{* * *} \\
\quad(0.037)\end{array}$ & $\begin{array}{l}0.84391 * * * \\
\quad(0.045)\end{array}$ \\
\hline Observations & 17,705 & 13,006 & 4,699 & 17,705 & 13,006 & 4,699 \\
\hline R-squared & 0.378 & 0.292 & 0.318 & 0.378 & 0.293 & 0.313 \\
\hline Instrument & IP Chile & IP Chile & IP Chile & IP Chile & IP Chile & IP Chile \\
\hline Method & 2SLS & 2SLS & 2SLS & 2SLS & 2SLS & 2SLS \\
\hline Underidentification p-value & 0.00165 & 0.00154 & 0.000344 & 0.00165 & 0.00154 & 0.000161 \\
\hline
\end{tabular}

Notes: Sample weights used in all estimations. Standard errors clustered at the sector-year level for estimations on Wages All (columns 1 and 4 ).

Standard errors are bootstrapped for estimations on Wages Informal (columns 2 and 5) and Wages Formal (columns 3 and 6 ). Individual controls

included: age, age2, gender, firm-size, education dummy levels. Year, department and sector fixed effects. ${ }^{* *} \mathrm{p}<0.01,{ }^{* *} \mathrm{p}<0.05,{ }^{*} \mathrm{p}<0.1$. 
also faded as it did on Table 8. However, as expected, given their prominence in the formal segment, the significant results on wages of the least educated disappear revealing that the negative effects previously observed were mostly driven by the presence of self-employed workers, who also, as we indicate above, happen to have lower levels of education.

\section{Conclusions}

The surge of exports from China and its impact on domestic labor markets worldwide has been largely documented. This paper adds to the literature by presenting the experience of the labor market in the manufacturing sector in Peru - a country that experienced a decade of unprecedented growth at the same time as the peak in the surge in China's exports to the world. Given the high proportion of informal workers in the Peruvian labor market, the focus of this work was the impact on informality and wages, accounting for the differences in workers' level of education.

The literature on the impact of the China shock has already established the presence of heterogeneous effects across different groups of workers, and the results for Peru are no different. We find evidence that the China shock had a detrimental effect on informality and wages in the informal sector for the least educated (least-skilled) workers, mostly self-employed, and a positive effect on wages for workers in the formal sector with elementary and high school education. The evidence is robust even as we account for the industry-level growth, and for the use of a different exclusion restriction in our estimations. The fact that the negative impact on wages of the least educated workers vanishes once self-employed workers are excluded reveals that the impact was mostly driven by their presence. There seems to be no significant impact on wages of informal workers who have an employer.

These mixed results point to the complexity in the impacts of trade shocks, and the various roles that imports from China play in domestic markets. While the surge of Chinese exports implied the introduction of lower-cost (final) goods that competed - were substitutes - with goods produced locally - putting a downward pressure on wages of workers in those affected industries-, it also implied the access to complementary (intermediate) goods at more competitive prices, that supported the development of other booming sectors - putting an upward pressure on the wages of workers in them.

From a policy perspective, this means that it is important to evaluate the adjustment costs associated to trade so the more vulnerable groups of the population-workers with no education and those with an elementary-level education - can be identified if they are displaced and assisted with policies and programs intended to mitigate the negative impacts. However, at the same time, to catalyze the benefits from trade in all its potential, besides facilitating market access to cheaper goods, it is also important to complement trade with policies that facilitate the flow of goods domestically, and that improve the business environment so that firms and workers in all industries with potential can seize the benefits from trade and thrive. 


\section{Appendix A - Correspondence Between Classifications}

\section{Table A.1}

Correspondence table between the ISIC 2-digit classification and the INEI classification.

\begin{tabular}{clc}
\hline $\begin{array}{c}\text { 2-digit } \\
\text { Sector }\end{array}$ & \multicolumn{1}{c}{ ISIC REV 3 } & $\begin{array}{c}\text { Classification } \\
\text { following INEI }\end{array}$ \\
\hline 15 & Manufacture of food products and beverages & 1 \\
16 & Manufacture of tobacco products & 1 \\
17 & Manufacture of textiles & 2 \\
18 & Manufacture of wearing apparel; dressing and dyeing of fur & 3 \\
19 & Tanning and dressing of leather; manufacture of luggage, handbags, saddlery, & 4 \\
& harness and footwear & \\
20 & Manufacture of wood and of products of wood and cork, except furniture; & 5 \\
& manufacture of articles of straw and plaiting materials & \\
21 & Manufacture of paper and paper products & 6 \\
22 & Publishing, printing and reproduction of recorded media & 7 \\
23 & Manufacture of coke, refined petroleum products and nuclear fuel & 8 \\
24 & Manufacture of chemicals and chemical products & 9 \\
25 & Manufacture of rubber and plastics products & 10 \\
26 & Manufacture of other non-metallic mineral products & 11 \\
27 & Manufacture of basic metals & 12 \\
28 & Manufacture of fabricated metal products, except machinery and equipment & 13 \\
29 & Manufacture of machinery and equipment n.e.c. & 14 \\
30 & Manufacture of office, accounting and computing machinery & 14 \\
31 & Manufacture of electrical machinery and apparatus n.e.c. & 15 \\
32 & Manufacture of radio, television and communication equipment and apparatus & 16 \\
33 & Manufacture of medical, precision and optical instruments, watches and clocks & 16 \\
34 & Manufacture of motor vehicles, trailers and semi-trailers & 17 \\
35 & Manufacture of other transport equipment & 17 \\
36 & Manufacture of furniture; manufacturing n.e.c. & 18 \\
\hline
\end{tabular}




\section{References}

Acemoglu, D., Autor, D., Dorn, D., Hanson, G. H., and Price, B. (2016). Import Competition and the Great US Employment Sag of the 2000s. Journal of Labor Economics 34(S1), S141-S198.

Araujo, M. C., Carneiro, P., Cruz-Aguayo, Y., and Schady, N. (2016). Teacher Quality and Learning Outcomes in Kindergarten. The Quarterly Journal of Economics 131(3), 14151453.

Autor, D., Dorn, D., and Hanson, G. H. (2013). The China Syndrome: Local Labor Market Effects of Import Competition in the United States. American Economic Review 103(6), 2121-2168.

Autor, D. Dorn, D., and Hanson, G. H. (2016). The China Shock: Learning from Labor Market Adjustment to Large Changes in Trade. Annual Review of Economics 8(1), 205-240.

Balsvik, R., Jensen, S., and Salvanes, K. (2015). Made in China, sold in Norway: Local labor market effects of an import shock. Journal of Public Economics 127, 137-144.

Bernard, A., Jensen, B., and Schott, P. (2006). Survival of the best fit: Exposure to low-wage countries and the (uneven) growth of U.S. manufacturing plants. Journal of International Economics 68(1), 219-237.

Blyde, J., Busso, M., Faggioni, V., and Romero, D. (2016). The Impact of Chinese Competition on Mexican Labor Outcomes. Unpublished Manuscript.

Cabral, S., Martins, P., dos Santos, J. P., and Tavares, M. (2018). Collateral Damage? Labour Market Effects of Competing with China-at Home and Abroad. IZA Discussion Paper No. 11790 .

Castellares, R. (2015). Competition and Quality Upgrading in Export Markets: The Case of Peruvian Apparel Exports. Banco Central de Reserva del Perú Working Paper No. 2015010.

Chacaltana, J. (2017). Peru, 2002-2012: Growth, structural change and formalization. CEPAL Review No. 199, 45-64.

Cisneros-Acevedo, C. (2021). Unfolding Trade Effect in Two Margins of Informality. The Peruvian Case. CESIFO Working Paper No. 9114.

Dix-Carneiro, R., and Kovak, B. (2017). Trade Liberalization and Regional Dynamics. American Economic Review 107(10), 2908-2946.

Dix-Carneiro, R., and Kovak, B. (2019). Margins of labor market adjustment to trade. Journal of International Economics 117, 125-142.

Dix-Carneiro, R., Goldberg, P., Meghir, C., and Ulyssea, G. (2021). Trade and Informality in the Presence of Labor Market Frictions and Regulations. NBER Working Paper No. 28391.

Ebenstein, A., Harrison, A., McMillan, M., and Phillips, S. (2014). Estimating the Impact of Trade and Offshoring on American Workers using the Current Population Surveys. The Review of Economics and Statistics 96(4), 581-595.

Edwards, L., and Jenkins, R. (2015). The Impact of Chinese Import Penetration on the South African Manufacturing Sector. The Journal of Development Studies 51(4), 447-463. 
Goldberg, P., and Pavcnik, N. (2003). The response of the informal sector to trade liberalization. Journal of Development Economics 72(2), 463-496.

Goldberg, P., and Pavcnik, N. (2005). Trade, wages, and the political economy of trade protection: evidence from the Colombian trade reforms. Journal of International Economics 66(1), 75-105.

Goldsmith-Pinkham P., Sorkin, I., and Swift, H. (2018). Bartik Instruments: What, When, Why, and How. NBER Working Paper No. 24408.

Instituto Nacional de Estadística e Informática. (2012). Oferta y demanda global 1991-2011, año base 1994. Lima: INEI.

Levy, S. (2018). Under-Rewarded Efforts: The Elusive Quest for Prosperity in Mexico. Washington: Inter-American Development Bank.

Loayza, N. (2007). The Causes and Consequences of Informality in Peru. Banco Central de Reserva del Perú Working Paper No. 2007-018.

Malgouyres, C. (2016). The Impact of Chinese Import Competition on the Local Structure of Employment and Wages: Evidence from France. Banque de France Working Paper No. 603.

McCaig, B., and Pavcnik, N. (2015). Informal Employment in a Growing and Globalizing LowIncome Country. American Economic Review 105(5), 545-550.

Medina, P. (2021). Import Competition, Quality Upgrading and Exporting: Evidence from the Peruvian Apparel Industry. Under revision.

Melitz, M. (2003). The Impact of Trade on Intra-Industry Reallocations and Aggregate Industry Productivity. Econometrica 71(6), 1695-1725.

Mion, G., and Zhu, L. (2013). Import competition from and offshoring to China: A curse or blessing for firms? Journal of International Economics 89(1), 202-215.

Molina, D. (2017). The China Effect on Colombia's Manufacturing Labor Market. Inter-American Development Bank Working Paper Nº 1101.

OECD/CIAT/IDB. (2016). Taxing Wages in Latin America and the Caribbean. OECD Publishing, Paris.

Paz, L. S. (2014). The impacts of trade liberalization on informal labor markets: A theoretical and empirical evaluation of the Brazilian case. Journal of International Economics 92(2), $330-348$.

Paz, L. S. (2017). The effect of import competition on Brazil's manufacturing labor market in the 2000s: Are imports from China different? The International Trade Journal 32(1), 76-99.

Paz, L. S., and Kapri, K. P. (2019). The Effects of the Chinese Imports on Brazilian Manufacturing Workers. Economies 7(3), 76.

Rabanal, J., and Rabanal, O. (2016). The Effect of Chinese Demand and Supply Shocks on Peruvian Exporters. Emerging Markets Finance and Trade 52(8), 1922-1934.

Stock, J., and Yogo, M. (2005). Testing for Weak Instruments in Linear IV Regression. In D. W. K. Andrews (Ed.), Identification and Inference for Econometric Models (pp. 80-108). New York: Cambridge University Press. 
Ulysea, G. (2020). Informality: Causes and Consequences for Development. Annual Review of Economics 12, 525-546.

Támola, A. (2014). Credit, Labor Formality and Firm Size: Analytical Framework and Regional Evidence in the Context of the IDB's Country Strategy Dialogue. IDB Technical Note No. 627. Washington: Inter-American Development Bank.

Yamashita, N. (2017). The People's Republic of China's Import Competition and Skill Demand in Japanese Manufacturing. Asian Development Bank Institute Working Paper No. 644. 